\title{
Total Peroxy Nitrates ( $\Sigma$ PNs) in the atmosphere: the Thermal Dissociation-Laser Induced Fluorescence (TD-LIF) technique and comparisons to speciated PAN measurements
}

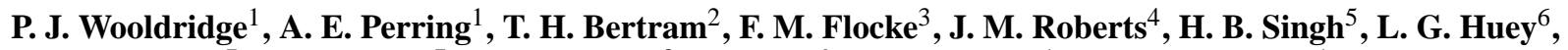 \\ J. A. Thornton ${ }^{7}$, G. M. Wolfe ${ }^{7}$, J. G. Murphy ${ }^{8}$, J. L. Fry ${ }^{9}$, A. W. Rollins ${ }^{1}$, B. W. LaFranchi ${ }^{1}$, and R. C. Cohen ${ }^{1,10}$ \\ ${ }^{1}$ Department of Chemistry, University of California, Berkeley, CA, USA \\ ${ }^{2}$ Department of Chemistry and Biochemistry, University of San Diego, La Jolla, CA, USA \\ ${ }^{3}$ NCAR Atmospheric Chemistry Division, Boulder, CO, USA \\ ${ }^{4}$ NOAA Earth System Research Laboratory, Boulder, CO, USA \\ ${ }^{5}$ NASA Ames Research Center, Moffett Field, CA, USA \\ ${ }^{6}$ School of Earth \& Atmospheric Sciences, Georgia Institute of Technology, Atlanta, GA, USA \\ ${ }^{7}$ Department of Atmospheric Sciences, University of Washington, Seattle, WA, USA \\ ${ }^{8}$ Department of Chemistry, University of Toronto, Toronto, Ontario, Canada \\ ${ }^{9}$ Department of Chemistry, Reed College, Portland, OR, USA \\ ${ }^{10}$ Department of Earth and Planetary Science, University of California, Berkeley, CA, USA
}

Received: 23 October 2009 - Published in Atmos. Meas. Tech. Discuss.: 4 December 2009

Revised: 24 March 2010 - Accepted: 6 April 2010 - Published: 12 May 2010

\begin{abstract}
Peroxyacetyl nitrate (PAN) and its chemical analogues are increasingly being quantified in the ambient atmosphere by thermal dissociation (TD) followed by detection of either the peroxyacyl radical or the $\mathrm{NO}_{2}$ product. Here we present details of the technique developed at University of California, Berkeley which detects the sum of all peroxynitrates $(\Sigma \mathrm{PNs})$ via laser-induced fluorescence (LIF) of the $\mathrm{NO}_{2}$ product. We review the various deployments and compare the Berkeley $\Sigma$ PNs measurements with the sums of PAN and its homologue species detected individually by other instruments. The observed TD-LIF $\Sigma$ PNs usually agree to within $10 \%$ with the summed individual species, thus arguing against the presence of significant concentrations of unmeasured PAN-type compounds in the atmosphere, as suggested by some photochemical mechanisms. Examples of poorer agreement are attributed to a sampling inlet design that is shown to be inappropriate for high $\mathrm{NO}_{\mathrm{x}}$ conditions. Interferences to the TD-LIF measurements are described along with strategies to minimize their effects.
\end{abstract}

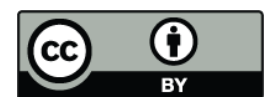

Correspondence to: P. J. Wooldridge (pjwool@berkeley.edu)

\section{Introduction}

Peroxy nitrates (molecules of the form $\mathrm{RO}_{2} \mathrm{NO}_{2}$, or PNs) are formed in the atmosphere from the association reaction of peroxy radicals $\left(\mathrm{HO}_{2}, \mathrm{RO}_{2}\right)$ with $\mathrm{NO}_{2}$, and can act as temporary reservoirs for $\mathrm{NO}_{\mathrm{x}}\left(=\mathrm{NO}+\mathrm{NO}_{2}\right)$ resulting in the transport of $\mathrm{NO}_{\mathrm{x}}$ far from source regions (e.g., Hudman, et al., 2004; Parrish, et al., 2004, 2009; Zhang, et al., 2008). PNs can be divided into two classes depending on the nature of the $\mathrm{RO}_{2}$ group: peroxy acyl nitrates (denoted here as PANs, also called acyl peroxy nitrates or peroxycarboxylic nitric anhydrides) where $\mathrm{RO}_{2}$ is $\mathrm{R}^{\prime} \mathrm{C}(\mathrm{O}) \mathrm{OO}$, and non-acyl peroxy nitrates where $\mathrm{RO}_{2}$ does not terminate with a peroxycarboxylic group or is $\mathrm{HO}_{2}$. PANs have thermal stabilities characteristic of the $\mathrm{RC}(\mathrm{O}) \mathrm{OO}-\mathrm{NO}_{2}$ bond, essentially independent of the nature of the R group (Roberts \& Bertman, 1992), that lead to lifetimes of minutes to hours in the lower troposphere $(\mathrm{T}>287 \mathrm{~K})$ and months in the upper troposphere $(\mathrm{T}<263 \mathrm{~K})$. Peroxyacetyl nitrate (PAN) and peroxypropionyl nitrate (PPN) are the most abundant, with PAN being generally 75 to $90 \%$ of observed individual species (Roberts, 1990; Roberts et al., 1998; Roberts, et al., 2002). Non-acyl PNs have markedly shorter thermal lifetimes and have significant concentrations only in the colder regions of the atmosphere (Murphy et al., 2004; Roberts, 2007; Kim et al., 2007; Salawitch, et al., 2002; Browne, et al., 2010).

Published by Copernicus Publications on behalf of the European Geosciences Union. 
Aldehyde oxidization and ketone photolysis are the typical precursors of PANs. These carbonyls are often secondary oxidation products (e.g., Singh, 1987, 2003), and relationships between concentrations of the generally observed PANs and the parent primary hydrocarbons have been explored (Roberts, et al., 2001; Roberts et al., 1998; Romero, et al., 2005; Cleary, et al., 2007; LaFranchi, et al., 2009). Photochemical oxidation mechanisms suggest that many other PNs may be formed in the atmosphere (Horowitz, et al., 1998; Bowman, et al., 2003; Cleary, et al., 2007). For example, a simple box model run using the isoprene oxidation sub-mechanism from the Master Chemical Mechanism (http://mcm.leeds.ac.uk/MCM/) (Saunders, et al., 2003) with isoprene and $\mathrm{NO}_{\mathrm{x}}$ both at ppbv levels generates species other than PAN, PPN, and MPAN (methacryloyl peroxynitrate) that can be as much as $40 \%$ of the PANs total. These other PAN species are mostly oxygenated, primarily $\mathrm{HOCH}_{2} \mathrm{C}(\mathrm{O}) \mathrm{OONO}_{2}$ for the isoprene case, whose formation reactions in the mechanism are stated to be "provisional". Theoretical structure and rate calculations (Méreau, et al., 2001) do predict the precursor association reaction $\mathrm{HOCH}_{2} \mathrm{CO}+\mathrm{O}_{2}+\mathrm{M} \rightarrow \mathrm{HOCH}_{2} \mathrm{C}(\mathrm{O}) \mathrm{OO}+\mathrm{M}$ to be much faster $\left(1.5 \times 10^{7} \mathrm{~s}^{-1}\right.$ vs. $3 \times 10^{4} \mathrm{~s}^{-1}$ at $1 \mathrm{~atm}$. $)$ than the decomposition pathway $\mathrm{HOCH}_{2} \mathrm{CO} \rightarrow \mathrm{CH}_{2} \mathrm{OH}+\mathrm{CO}$. Conversely, decomposition is predicted to be much more rapid for the case of $\mathrm{HC}(\mathrm{O}) \mathrm{CO}$, in agreement with the experiments of Orlando and Tyndall (2001).

There are a variety of aldehydes which have been measured for which the corresponding PAN has not yet been detected in the atmosphere (McClenny et al, 1998; Wedel, et al., 1998; Grossman, et al., 2003). For example, significant levels of nonanal have been measured in air impacted by biogenic emissions (Yokouchi, et al., 1990; Bowman, et al., 2003). Bowman, et al. (2003) complemented those measurements with laboratory studies of the peroxynonanyl nitrate yield to suggest that the higher molecular weight PANs could compose a significant fraction of the overall organic nitrogen. Additionally, Lewis, et al. (2000) suggested that a substantial amount of chemically stable, physically volatile, $\mathrm{C}_{9}-\mathrm{C}_{11}$ oxygenated compounds are present in urban atmospheres (see also Cicciolli \& Mannozzi, 2007). These would also be predicted to be precursors to PAN-like molecules.

It must be noted, however, that with the heavier aldehydes the reaction with $\mathrm{OH}$ becomes less likely to extract the aldehydic hydrogen to form the peroxyacyl radical. In the case of nonanal the likelihood is estimated to be around $50 \%$, rather than $\sim 100 \%$ for acetaldehyde (Tyndall, et al., 2002) and 95 \& $90 \%$ for $\mathrm{C}_{3} \& \mathrm{C}_{4}$ aldehydes (Bowman, et al., 2003). And finally, not all aldehydes are necessarily parents of PANs at all. For example, using the EUPHORE outdoor simulation chamber, Carrasco, et al. (2006) studied the fate of 2-hydroxy-2-methylpropanal ( $\left.\mathrm{HMPr}, \mathrm{HOC}\left(\mathrm{CH}_{3}\right)_{2} \mathrm{C}(\mathrm{O}) \mathrm{H}\right)$, a photo-oxidation product of 2-methyl-3-buten-2-ol (MBO), and observed a $100 \%$ apparent yield for acetone production following reaction with $\mathrm{OH}$, whether $\mathrm{NO}_{\mathrm{x}}$ was present or not, apparently indicating the corresponding PAN is not formed. This result agrees with Méreau, et al. (2001) prediction that decomposition should dominate over $\mathrm{O}_{2}$ addition for the $\mathrm{HOC}\left(\mathrm{CH}_{3}\right)_{2} \mathrm{CO}$ radical, but disagrees with the MCM prediction of the PAN analog $\mathrm{HOC}\left(\mathrm{CH}_{3}\right)_{2} \mathrm{C}(\mathrm{O}) \mathrm{OONO}_{2}$ being formed.

The importance of $\mathrm{NO}_{3}$ to the fate of isoprene has recently been recognized (Horowitz et al., 2007; Brown, et al., 2009; Perring, et al., 2009a; Rollins, et al., 2009). The primary product of that reaction is the aldehyde $\mathrm{CH}_{2}\left(\mathrm{ONO}_{2}\right) \mathrm{C}\left(\mathrm{CH}_{3}\right) \mathrm{CHCHO}$. Because $\mathrm{NO}_{3}$ will also abstract aldehydic hydrogens, the nighttime $\mathrm{NO}_{3}$ reactions with isoprene and other biogenic hydrocarbons could potentially lead to the formation of PANs. The reaction rates for the abstraction step, however, are likely too slow (see e.g., D'Anna et al., 2001; Cabañas et al., 2003) for this to be important.

Although PAN was first identified and measured in the atmosphere by long path infrared absorbance spectroscopy, and PAN in the upper troposphere has been observed by satellite using infrared emission spectra (Glatthor, et al., 2007), most measurements of PANs have used gas chromatography, typically with electron capture detection (GC/ECD) (Stephens, 1969; Roberts, 2007). While the $\mathrm{GC} / \mathrm{ECD}$ is a sensitive and reliable method for measuring $\mathrm{C}_{2^{-}}$ $\mathrm{C}_{4}$ PANs, the response to larger PANs is known to be lower, probably due to some combination of thermal loss during the longer elution times and a decline in the ECD signal with increasing size of the R-group (Flocke, et al., 2005).

A number of measurement techniques based on the ready thermal dissociation of PANs to yield $\mathrm{NO}_{2}$ and peroxy radicals have been reported. Blanchard, et al. (1990) used thermal dissociation followed by luminol detection of the $\mathrm{NO}_{2}$ product after the GC column. Later work (Blanchard, et al., 1993) added the chemical amplification of $\mathrm{NO}$ to $\mathrm{NO}_{2}$ by peroxy radicals in the presence of CO. Nikitas, et al. (1997) used Luminol II solutions and omitted the separation column and considered PAN to be the $\mathrm{NO}_{2}$ difference between an unheated sample stream and one that had been directed through a thermal converter. The $\mathrm{NO}_{2}$ thermolysis product has also been detected by LIF (Day et al., 2002; Di Carlo et al; 2008), photolysis/chemiluminescence (Alaghmand, et al., 2008), and by cavity ring down spectroscopy (Paul, et al., 2009). Thermal dissociation-chemical ionization mass spectrometric (TD-CIMS) techniques measuring the peroxyacyl radical product have been implemented for field measurements in the past few years (Slusher et al., 2004), including for eddy covariance fluxes (Turnipseed, et al., 2006; Wolfe, et al., 2008).

The TD-LIF technique doesn't directly measure individual PN species, but rather the sum of all species that yield $\mathrm{NO}_{2}$ within a certain range of heating conditions: total PNs (or $\Sigma \mathrm{PNs}$ ) is the difference between the $\mathrm{NO}_{2}$ signal from a heated inlet and that from an unheated inlet. This would include not only PANs, but also $\mathrm{N}_{2} \mathrm{O}_{5}, \mathrm{ClONO}_{2}, \mathrm{BrONO}_{2}$, 


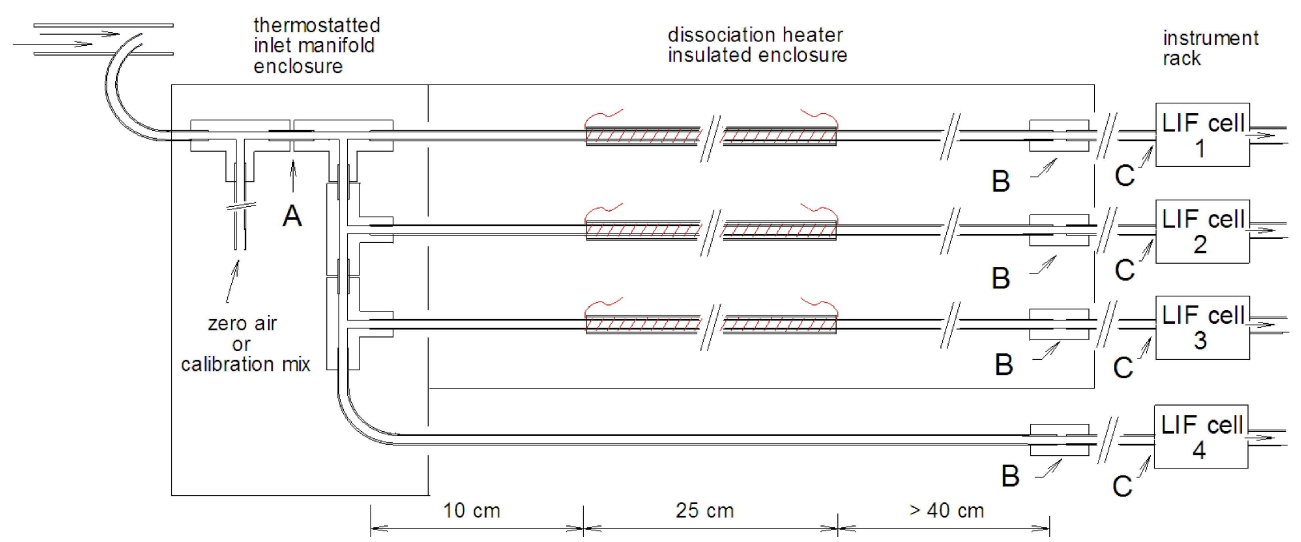

Fig. 1. Schematic of the sampling system. Different instrument configurations have had pressure reduction at points A, B, or C.

$\mathrm{HO}_{2} \mathrm{NO}_{2}, \mathrm{CH}_{3} \mathrm{O}_{2} \mathrm{NO}_{2}$, etc., if present in the atmosphere and if transmitted through the inlet tubing to the heater (Fig. 1).

Here we compare ambient and chamber TD-LIF measurements of $\Sigma$ PNs to summed individual species ( $\Sigma$ PANs) from distinct independent methods. The measurements occurred over a span of eight years and include several variations in configurations of TD-LIF sampling inlets and a variety of speciated PANs detection techniques. We explore the agreement under this large range of ambient conditions and assess possible interferences to TD-LIF measurements. We also use the comparison to assess the potential presence of other PN species in the atmosphere that have not been reported using current techniques.

\section{The TD-LIF technique for the determination of $\Sigma$ PNs}

\subsection{Instrument construction and operation}

The Berkeley instrument detects species that contain - O$\mathrm{NO}_{2}$ groups by thermal dissociation (TD) followed by laserinduced fluorescence (LIF) of the $\mathrm{NO}_{2}$ product, was first described by Day, et al. (2002). Over the last decade, a number of sampling and detection variations have been implemented. Figure 1 depicts the general scheme for sampling and dissociation plumbing for an instrument that measures molecules of the form $\mathrm{RONO}_{2}$ (the sum of alkyl nitrates, or $\Sigma \mathrm{ANs}$ ) and $\mathrm{HNO}_{3}$ in addition to $\mathrm{NO}_{2}$ and $\Sigma$ PNs. The design minimizes the amount of plumbing between the inlet tip and the dissociation heaters to minimize wall interactions, which is particularly important for the detection of $\mathrm{HNO}_{3}$. The PFA Teflon inlet manifold region is thermostatted to $50-80^{\circ} \mathrm{C}$ to minimize $\mathrm{HNO}_{3}$ sticking to the walls (Neuman, et al., 2000) without dissociating PNs. The dissociation heaters are $1 / 4$ " $(6.35 \mathrm{~mm})$ o.d. quartz tubing wrapped with Nichrome wire and sheathed with larger diameter quartz tubes. Typically heater \#1 would be set for $\mathrm{HNO}_{3}$ dissociation $\left(550-650^{\circ} \mathrm{C}\right)$, $\# 2$ for $\Sigma$ ANs $\left(350-400^{\circ} \mathrm{C}\right), \# 3$ for $\Sigma$ PNs $\left(150-200^{\circ} \mathrm{C}\right)$, and $\# 4$ for $\mathrm{NO}_{2}$ (unheated, $<40^{\circ} \mathrm{C}$ ). Flow rates are 1-2 SLPM through each. For ground site measurements we use a small blower to pull air past a rearward hooked tube to exclude very large particles and other debris.

The LIF cells are operated at pressures $<5 \mathrm{hPa}$ in order to extend the $\mathrm{NO}_{2}$ fluorescence lifetime beyond $100 \mathrm{~ns}$ for the time-gated LIF technique (Thornton, et al., 2000), and the constriction to reduce the pressure may be inserted in a number of places (A, B, C in Fig. 1) between the tip and cells. The different locations for the constriction trade off factors such as sensitivity and susceptibility to interferences versus instrument size and power consumption. When sampling through long lines (1/4" o.d. PFA Teflon) from tower mounted inlets/heaters, stainless steel pinholes were originally placed just after the gas stream re-cools, at the quartz to Teflon tube junctions (points B in Fig. 1) (Day, et al., 2002; Murphy, et al., 2004; Rosen, et al., 2004; Cleary, 2005). Compared to placing the orifice just prior to the detection cells (points $\mathrm{C}$ in Fig. 1), this gives much quicker gas transit times as well as much reduced potential for interfering chemical reactions. During most aircraft deployments (and some ground campaigns with short towers), jet expansions have been employed to cool the gas and increase the fraction of $\mathrm{NO}_{2}$ molecules in the low rotational states being probed and thereby increase the detection sensitivity (Cleary, 2002). In this case the pressure reduction is at the expansion nozzle inside the LIF cell (points C). Most recently, a system with a glass orifice before the heaters (point A) has been implemented in order to reduce interferences caused by high levels of $\mathrm{NO}_{\mathrm{x}}$ and $\mathrm{O}_{3}$, as discussed below.

Dedicating one LIF detection cell for each of the four sample lines as depicted in Fig. 1 is the most straightforward and has the most complete temporal coverage. For lower weight, cost, and power, some deployments have employed 3-way Teflon valves to rapidly switch the sample streams of four heaters to a pair of cells (Murphy, et al., 2006; Bertram, et al., 2007; Perring, et al., 2009b). Alternatively, two inlet heaters may be used with temperature cycling, but at the expense of temporal data coverage (e.g., Rosen, et al., 2004). 


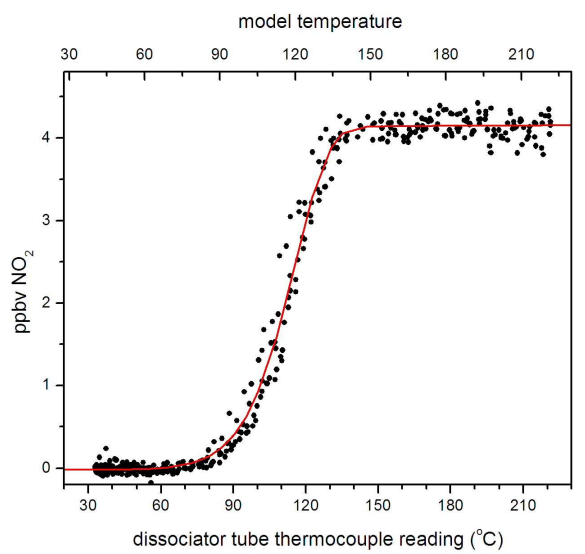

Fig. 2. Kinetic model and laboratory measurement of $\mathrm{NO}_{2}$ dissociation product versus temperature for PAN.

We model the chemical evolution of PAN, peroxyacyl (PA) radicals, $\mathrm{NO}, \mathrm{NO}_{2}$, and $\mathrm{O}_{3}$ in air from the inlet tip to the LIF cell as a plug flow reactor with a prescribed temperature profile. For our $3.6 \mathrm{~mm}$ i.d. quartz tubes we use a $7.5 \mathrm{~cm}$ temperature transition region from ambient to the set point, $17 \mathrm{~cm}$ at the dissociation temperature set point, then $23 \mathrm{~cm}$ to cool back to ambient temperature, followed by transit through ambient temperature Teflon tubing to the LIF $\mathrm{NO}_{2}$ measurement cell. The flow rate is set at 2 SLPM, and the rate constants are the same as in Day, et al. (2002). No attempt is made to measure the true air temperature inside the heated quartz tubes, instead external thermocouples are used and the characteristic dissociation temperatures for individual tubes are determined by temperature scans with reference compounds (i.e. PAN, $\mathrm{n}-\mathrm{C}_{3} \mathrm{H}_{7} \mathrm{ONO}_{2}$, and $\mathrm{HNO}_{3}$ ). Figure 2 presents a temperature scan from PAN synthesized in the laboratory carried in zero air at 1 atmosphere. Results from the kinetic model are also shown.

Figure 3 shows the results of simulations for atmospheric trace species that yield $\mathrm{NO}_{2}$ upon thermal dissociation under these conditions, with pressure reduction at point B. Rate constants were added for $\mathrm{ClNO}_{2}$ (Baulch, et al., 1981; Knauth and Martin, 1978), $\mathrm{BrONO}_{2}$ (Orlando \& Tyndall, 1996), $\mathrm{ClONO}_{2}$ (Anderson \& Fahey, 1990), and $\mathrm{CH}_{3} \mathrm{OONO}_{2}$ (Zabel, et al., 1989). The dissociation temperatures of these species have not been experimentally verified for this instrument, but it has been reported that nitryl chloride $\left(\mathrm{ClNO}_{2}\right)$ requires a higher temperature for dissociation than that normally used for measurement of PANs (Osthoff, et al., 2008). The $\Sigma$ PNs heater temperature is chosen to completely dissociate PAN and related species but to have interferences of less than $1 \%$ from the next higher class by thermal stability ( $\Sigma \mathrm{ANs})$. When the pressure reduction is before the heater (point $\mathrm{A}$ in Fig. 1), the shorter residence times require higher temperatures: for a 2 SLPM flow we calculate a $+45^{\circ} \mathrm{C}$ difference for a heater at 0.2 atm versus

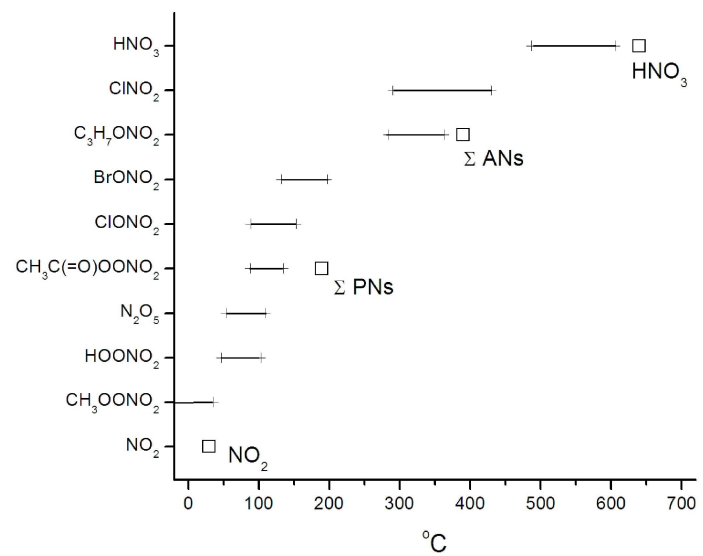

Fig. 3. Modeled 5 to $95 \%$ dissociation temperature ranges (plusses) and typical TD-LIF setpoints (squares).

one at $1 \mathrm{~atm}$. This change is small enough that a single set point may be used in airborne applications without active inlet pressure control.

\subsection{Calibration}

Instruments that detect PAN specifically are generally calibrated either with the vapor diffusing from laboratorysynthesized PAN dissolved in a low vapor pressure hydrocarbon solvent, or by PAN synthesized in the gas phase on demand. Both systems are secondary calibrations by reference to an $\mathrm{NO}$ or $\mathrm{NO}_{2}$ standard. In the gas phase synthesis method, an excess of peroxyacetyl radicals is created by photolyzing acetone at $285 \mathrm{~nm}$, which is combined with a known amount of $\mathrm{NO}$ or $\mathrm{NO}_{2}$ (e.g. Roberts, et al., 2002). Generally, $93 \%$ or more is converted to PAN, however if the mercury lamp's phosphor coating is damaged the $254 \mathrm{~nm} \mathrm{Hg}$ line will photolyze PAN effectively. In addition, self reactions of the excess peroxy radicals result in high concentrations of peroxides and other byproducts which interfere with some detection schemes. The diffusion source is usually calibrated by catalytic conversion of its output to NO followed by ozone chemiluminescence detection, coupled either to the assumption that $\mathrm{NO}_{y}$ impurities (typically $\mathrm{CH}_{3} \mathrm{ONO}_{2}, \mathrm{NO}_{2}$, and $\mathrm{HNO}_{3}$ ) are negligible or are directly measured.

The TD-LIF technique takes advantage of the quantitative yield of $\mathrm{NO}_{2}$ from PAN thermal decomposition. As such, the calibration doesn't require a PAN standard but uses certified standard $\mathrm{NO}_{2}$ in $\mathrm{N}_{2}$ mixtures, typically 5 or 10 ppmv. Just prior to each calibration the regulator and plumbing are purged by briefly opening a vented solenoid valve next to the mass flow controller. The standard is diluted with zero air to $0-20 \mathrm{ppbv}$ in 2 to 4 steps, and the inlet is overflowed with the mixture at the tip and prior to the split between channels such that each sees the same calibration gas, as shown in Fig. 1. Comparisons of the $\mathrm{NO}_{2}$ measured by LIF and photolysis/chemiluminescence have shown agreement to better 
than 5\% (Thornton, et at., 2003; Fuchs, et al., 2009). To ensure good channel-to-channel precision for the subtractions, calibrations are performed every few hours during ground site measurements. For airborne campaigns these calibrations are made more frequently and initiated in response to changing ambient pressure.

\subsection{Instrument performance}

Two different types of lasers have been used in the Berkeley LIF instruments. The pulsed dye laser system has been described previously (Thornton, et al., 2000). This laser provides $100-200 \mathrm{~mW}$ at $8 \mathrm{kHz}$ repetition rate and is tuned on and off of a molecular rovibronic line at $17086.5 \mathrm{~cm}^{-1}$ $(585.1 \mathrm{~nm})$. Alternatively, small and efficient diode lasers in the $405-410 \mathrm{~nm}$ region have been used to take advantage of the larger $\mathrm{NO}_{2}$ absorption cross-section $\left(\sigma \approx 6 \times 10^{-19} \mathrm{~cm}^{-2}\right.$ at $408 \mathrm{~nm}$ vs. $\approx 1 \times 10^{-19}$ at $\left.585.1 \mathrm{~nm}\right)$. The disadvantages of the diodes thus far have been lower power $(<40 \mathrm{~mW})$ and a sharply restricted tuning range $\left(0.3 \mathrm{~cm}^{-1}\right.$ vs. $\left.6 \mathrm{~cm}^{-1}\right)$. Additionally, time-gated fluorescence detection is effected by turning the diode current on and off, which further reduces the average excitation power. We have used both external cavity tunable diodes (Toptica model DL-100) and modules without wavelength tuning (Power Technology Inc., IQ series).

The signal-to-noise ratio (SNR) of an individual $\mathrm{NO}_{2}$ measurement is determined by the photon count rate per ppbv $\mathrm{NO}_{2}$ and the background count rate. The dye laser system has a slope (S) of 60 counts s ${ }^{-1} \mathrm{ppbv}^{-1}$ with 20 counts s $\mathrm{s}^{-1}$ background (B) at $120 \mathrm{~mW}$ laser power. Cell versus cell relative slopes are within $1 \%$. With $10 \mathrm{~s}$ of averaging, photon counting statistics gives an uncertainty for a $\mathrm{NO}_{2}$ measurement of $\sigma_{\mathrm{NO}_{2}}=[\sqrt{ }(2 \mathrm{~B} / \mathrm{t})] / \mathrm{S} \approx 35 \mathrm{pptv}$, for a detection limit of $70 \mathrm{pptv}$ at $\mathrm{SNR}=2$. Also for $10 \mathrm{~s}$ averaging, $\sigma_{\mathrm{NO}_{2}}=5$ $10 \mathrm{pptv}$ for the dye laser/jet expansion system (depending on flight altitude), and $\approx 50 \mathrm{pptv}$ for the $408 \mathrm{~nm}$ diode laser systems. For the $\Sigma$ PNs subtraction difference, the SNR is $(\mathrm{C} 2-\mathrm{C} 1) / \sqrt{ }\left(\sigma_{C 2}^{2}+\sigma_{C 1}^{2}\right)$, where $\mathrm{C} 2$ and $\mathrm{C} 1$ are the concentrations for the heated and unheated channels. This ratio degrades as the ambient $\left[\mathrm{NO}_{2}\right]$ becomes large compared to the net $[\Sigma \mathrm{PNs}]$.

\subsection{Accuracy}

Factors affecting the accuracy of TD-LIF measurements have been discussed by Day, et al. (2002) and Rosen, et al. (2004). The effect of the $\mathrm{NO}+\mathrm{O}_{3}$ reaction on photoconversion/chemiluminescence measurements of $\mathrm{NO}_{2}$ has been discussed by Ryerson, et al. (2000). Here the interference due to Reaction 1 below is generally less than $1 \%$ of the NO converted to $\mathrm{NO}_{2}$ by $\mathrm{O}_{3}$. The much faster rate for $\mathrm{NO}+\mathrm{RO}_{2}$ (Reaction 2, with $\mathrm{RO}_{2}$ written specifically as $\mathrm{CH}_{3} \mathrm{C}(\mathrm{O}) \mathrm{OO}$ from PAN dissociation) converts less than $5 \%$ of NO.

$$
\begin{aligned}
& \mathrm{NO}+\mathrm{O}_{3} \rightarrow \mathrm{NO}_{2}+\mathrm{O}_{2} \\
& \mathrm{NO}+\mathrm{CH}_{3} \mathrm{C}(\mathrm{O}) \mathrm{OO}+\mathrm{O}_{2} \rightarrow \mathrm{CH}_{3} \mathrm{OO}+\mathrm{CO}_{2}+\mathrm{NO}_{2}
\end{aligned}
$$

At very high NO concentrations (100s to $1000 \mathrm{~s}$ of ppbv), up to $4 \mathrm{NO}_{2}$ molecules for each PAN could in principle be generated by including the further reactions:

$$
\begin{aligned}
& \mathrm{NO}+\mathrm{CH}_{3} \mathrm{OO}+\mathrm{O}_{2} \rightarrow \mathrm{HCHO}+\mathrm{HO}_{2}+\mathrm{NO}_{2} \\
& \mathrm{NO}+\mathrm{HO}_{2} \rightarrow \mathrm{OH}+\mathrm{NO}_{2} .
\end{aligned}
$$

The chemical amplification scheme mentioned earlier (Blanchard, et al., 1993) exploits this by adding percent levels of $\mathrm{CO}$ to recycle $\mathrm{OH}$ to $\mathrm{HO}_{2}$ via the reaction $\mathrm{CO}+\mathrm{OH}$ $+\mathrm{O}_{2} \rightarrow \mathrm{CO}_{2}+\mathrm{HO}_{2}$. Ambient concentrations of $\mathrm{CO}$ are much too small to yield detectable amplification.

Elevated concentrations of $\mathrm{NO}_{2}$, in addition to lowering the signal-to-noise ratio of the subtraction difference, accelerate the recombination kinetics of the PNs after the heated section leading to the underestimation of $\Sigma$ PNs, also on the order of $5 \%$ or less under typical conditions. The extent of the interferences varies with both residence time and number density, both of which are affected by the choice of the pressure reduction point.

Figure 4 shows the results of simulations for a system initialized with 5 ppbv $\mathrm{NO}_{2}, 1$ ppbv NO, 2 ppbv PAN, and $60 \mathrm{ppbv} \mathrm{O}_{3}$ and with $6.5 \mathrm{~m}$ of Teflon tubing between the heated quartz inlet tube and the $\mathrm{NO}_{2} \mathrm{LIF}$ detection cell. The high $\mathrm{NO}_{\mathrm{x}}$ level used here was chosen to be representative of conditions encountered during the Boulder, 2005 campaign discussed below. The $\mathrm{NO}_{2}, \mathrm{NO}$ and PAN concentrations are unchanged by the transit through the $50{ }^{\circ} \mathrm{C}$ inlet tip (0-.05 s), then the PAN is completely dissociated to $\mathrm{NO}_{2}$ and PA in the $180{ }^{\circ} \mathrm{C}$ heated zone $(.05-.15 \mathrm{~s})$. Ideally there would be no $\mathrm{NO}_{2}+\mathrm{PA} \rightarrow$ PAN recombination or $\mathrm{NO}+\mathrm{PA} \rightarrow \mathrm{NO}_{2}$ conversion during the cooling and transit to the LIF cell $(>.15 \mathrm{~s})$, however these effects are evident in the atmospheric pressure case shown in the middle frame. In this simulation there is significant loss of $\mathrm{NO}_{2}$ signal to PAN recombination $(-28 \%)$ and also gain of $\mathrm{NO}_{2}$ signal from $\mathrm{NO}$ oxidation $(+10 \%)$. Early pressure reduction reduces both number density of the reactants and the transit time between the inlet tip and the LIF cell, resulting in lowering the interfering $\mathrm{NO}_{2}$ reactions to less than $3 \%$ in this example.

Wall loss rates of the PA radical are the key adjustable parameters in the model. Results from laboratory characterizations of various concentrations of PAN, $\mathrm{NO}, \mathrm{NO}_{2}$, and $\mathrm{H}_{2} \mathrm{O}$ with pressure reduction at points $\mathrm{B}$, were used to tune the wall loss rates $(\gamma)$ for the PA radicals to the quartz heater and Teflon transit tubing. The combination of $\gamma=.3$ for loss to quartz and $\gamma=.2$ for Teflon best fit the data. The elevated temperatures should minimize the influence of relative humidity variations and condensable organic species in the sampled air; however the $\gamma$ will likely vary some between individual quartz tubing pieces and with environmental exposure. 

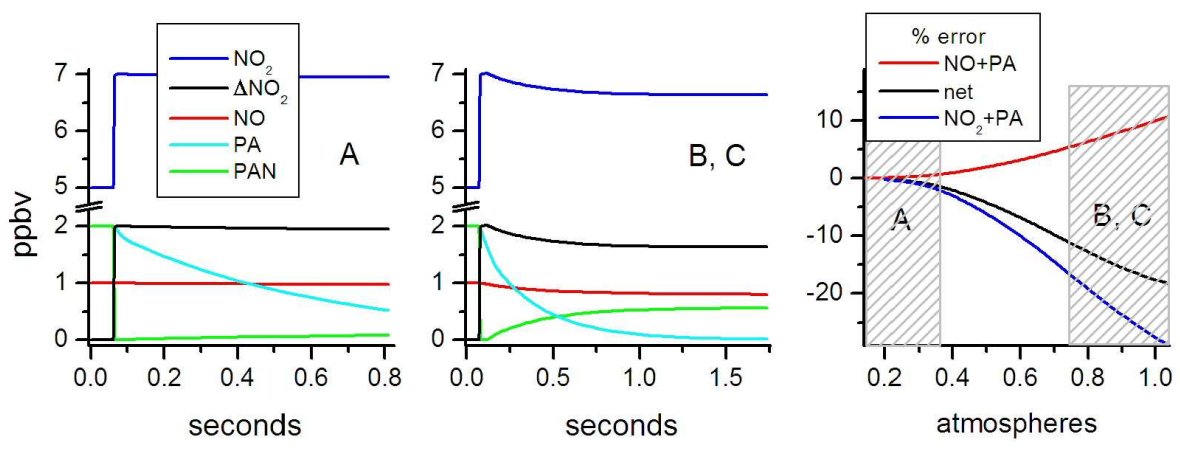

Fig. 4. Modeled evolution from inlet tip to LIF cell for systems with pressure reduction at the tip (position A, left frame) or after the heater (position $\mathrm{B}$ or $\mathrm{C}$, middle frame). The PAN signal is the difference between the final $\mathrm{NO}_{2}$ and the ambient initial $\mathrm{NO}_{2}(5 \mathrm{pbbv})$, i.e. PAN signal $=\Delta \mathrm{NO}_{2} \approx 2 \mathrm{ppbv}$. The right frame shows the final percent errors versus the pressure in the heater.
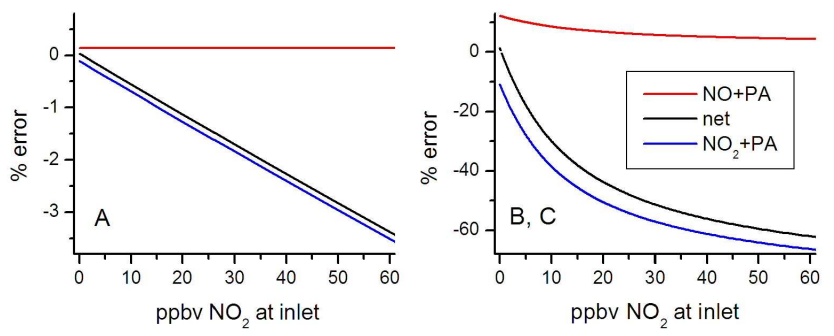

Fig. 5. Modeled final concentrations at the LIF cell with the pressure drop at point $\mathrm{A}$ (on left) or points $\mathrm{B}, \mathrm{C}$ (on right) as a function of $\left[\mathrm{NO}_{2}\right]$ at constant $1 \mathrm{ppbv} \mathrm{NO}$ and $60 \mathrm{ppbv} \mathrm{O}_{3}$. Note the factor of 20 difference in scale.

Figures 5 and 6 demonstrate the effect of increasing $\mathrm{NO}_{2}$ and NO concentrations on the $\Sigma$ PNs signal, under the same conditions as for Fig. 4. These are somewhat extreme cases because either $[\mathrm{NO}]$ or $\left[\mathrm{NO}_{2}\right]$ is fixed and so the $[\mathrm{NO}] /\left[\mathrm{NO}_{2}\right]$ ratio covers a very wide range. In Fig. 5 the extra $\Sigma$ PNs signal $\left(\Delta \mathrm{NO}_{2}\right)$ at low $\mathrm{NO}_{2}$ is from $\mathrm{NO}$ oxidation. Very large $\mathrm{NO}$ concentrations coincident with $60 \mathrm{ppbv}$ of $\mathrm{O}_{3}$ could produce a large amount of $\mathrm{NO}_{2}$ in the atmospheric pressure inlet (Fig. 6), a scenario that is unrealistic in the atmosphere.

Overall, model calculations indicate that when the dissociation occurs at 1 atmosphere pressure $\mathrm{NO}+\mathrm{PA}$ and $\mathrm{NO}_{2}+\mathrm{PA}$ reactions may require correction terms as large as $30 \%$ in the PAN measurement when $\mathrm{NO}$ and $\mathrm{NO}_{2}$ are higher than 3 and 4 ppbv, respectively. The terms have opposite signs and the degree of cancellation will depend on the $\mathrm{NO}_{2} / \mathrm{NO}$ ratio. With the pressure drop before the dissociation (point $\mathrm{A}$ ) the effects should be negligible even at high $\mathrm{NO}$ and $\mathrm{NO}_{2}$ levels. These results are used to interpret the comparisons described below.

\subsection{Data treatment}

For routine application to large datasets taken with atmospheric pressure dissociation, a parameterization for the corrections was derived. Positive interference to $\mathrm{NO}_{2}$ from the
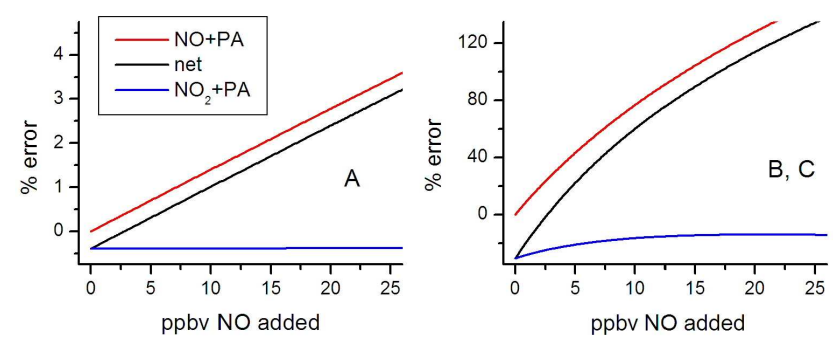

Fig. 6. As in Fig. 5, but as a function of $[\mathrm{NO}]$ at the inlet tip with 5 ppbv $\mathrm{NO}_{2}$ and 60 ppbv $\mathrm{O} 3$.

reaction of $\mathrm{NO}$ with $\mathrm{O}_{3}$ between the inlet tip and the cells has been found to be small for nearly all conditions encountered, and would not affect the difference as it would be the very nearly the same for both the heated and unheated channels. Positive interference from the NO+PA $\rightarrow \mathrm{NO}_{2}$ reaction is parameterized as $\mathrm{k}_{\mathrm{NO}+\mathrm{PA}}(\mathrm{T})[\mathrm{PA}][\mathrm{NO}] \tau$, where $\tau$ and $\mathrm{T}$ are the characteristic time (typically $<0.1 \mathrm{~s}$ ) and effective average temperature (typically $323 \mathrm{~K}$ ) for the heater to cell transit that best reproduces the results from the laboratory experiments and detailed model. This incorporates the heater temperature profile, PA loss coefficients, etc., into two parameters. Negative interference from the $\mathrm{NO}_{2}+\mathrm{PA} \rightarrow \mathrm{PAN}$ recombination is taken as $\mathrm{k}_{\mathrm{NO} 2+\mathrm{PA}}(\mathrm{M}, \mathrm{T})[\mathrm{PA}]\left[\mathrm{NO}_{2}\right] \tau$, where $\mathrm{M}$ is from the measured pressure in the tubing and $\tau$ and $\mathrm{T}$ are the same as above. The uncorrected [ $\Sigma \mathrm{PN}]$ measurement is used as an initial approximation for [PA]. An iterative procedure where the corrected $[\Sigma \mathrm{PNs}]$ value used to refine the initial [PA] was explored in early work, but it was determined that points where this would lead to significant additional changes should be discarded as unreliable.

In general, the correction terms for both effects have been small $(<5 \%)$ for non-urban environments $\left(\mathrm{NO}_{\mathrm{x}}<3 \mathrm{ppbv}\right)$. For airborne deployments in particular both of the terms have been insignificant except during brief transits of fresh combustion plumes at low altitudes. We have retained the jet expansion (at point $\mathrm{C}$ ) in this case for the factor of ten or higher 


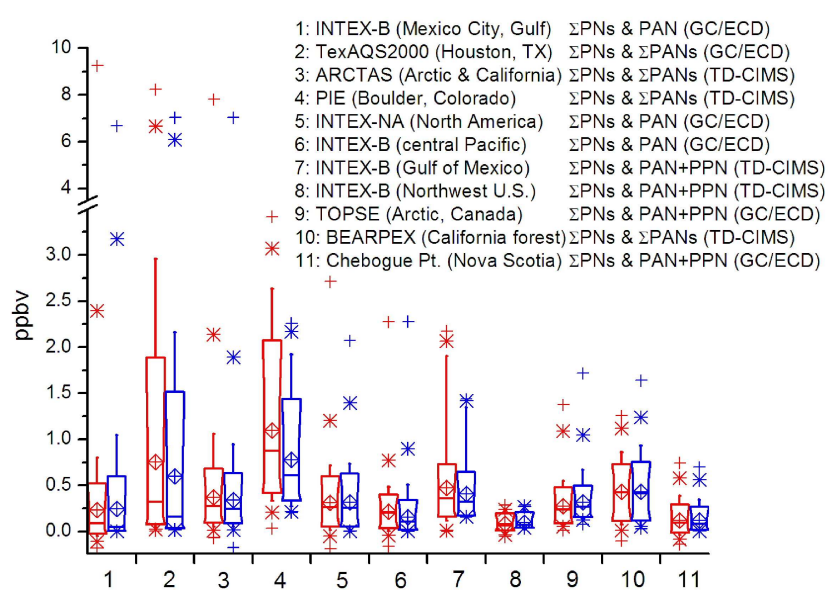

Fig. 7. Statistical overview of campaigns with comparison opportunities. Boxes delineate 10 to 90 percentiles, whiskers extend 5 to $95 \%, *$ are 1 and $99 \%$, and + are minima and maxima. Lines through the boxes depict the medians and diamonds are the means. Red (left in the pairs) are TD-LIF $\Sigma$ PNs and blue (right) are PAN or summed individual species, as available.

gain in sensitivity when used with the tunable dye laser. On the other hand, for recent surface site deployments where high $\mathrm{NO}_{\mathrm{x}}$ values were anticipated (i.e. Mexico City, SAPHIR chamber) we have placed the pressure reduction orifice before (point A) the heated section instead of after (point B or C).

\section{Field and chamber measurements overview}

Table 1 lists 14 deployments with TD-LIF participation from 2000 through 2008, and Fig. 7 presents a statistical overview of the range of concentrations encountered during the campaigns with comparison opportunities. These have been aboard aircraft, at ground sites, and in controlled atmosphere chambers. The conditions have ranged from clean remote where PAN is often the dominant $\mathrm{NO}_{\mathrm{y}}$ component, to heavily urban impacted where $\mathrm{NO}$ and $\mathrm{NO}_{2}$ largely exceed other $\mathrm{NO}_{\mathrm{y}}$ species.

For the comparisons, careful alignments of the timebases of datasets are performed before making correlation plots. A weighted total least squares algorithm (Krystek \& Anton, 2007) was used, with $1 /(15 \%+.005 \mathrm{ppbv})$ and $1 /(15 \%+.05 \mathrm{ppbv})$ used as generic weights for the GC/ECD (or TD-CIMS) data and the TD-LIF data, respectively when the values were not stated in the dataset. The results are shown in Table 2 and Fig. 8. Also shown are histograms indicating whether the $\Sigma \mathrm{PNs}+\mathrm{NO}_{2}$ signal was dominated by $\mathrm{NO}_{2}$ (values close to 0 ) or $\Sigma$ PNs (values close to 1 ).

\subsection{Airborne measurements}

The airborne deployments have all utilized the same instrument with the pressure reduction point after the heater and near to or inside of the LIF cell (point C in Fig. 1). For the TOPSE mission (Atlas, et al., 2003) on the NSF/NCAR C130 aircraft we used an instrument with one channel dedicated to measuring $\mathrm{NO}_{2}$ and the other to $\Sigma$ PNs. The instrument occupied one standard "high" rack having 2 bays for $19^{\prime \prime}$ panel mounted equipment ( $44 \mathrm{~cm}$ instrument width), each $127 \mathrm{~cm}$ tall and $64 \mathrm{~cm}$ deep. Total weight was approximately $270 \mathrm{~kg}$ and power consumption was about $2 \mathrm{~kW}$. The inlet was machined from PFA Teflon following the design of Ryerson, et al. (1999). Pinholes just prior to each LIF cell gave pressures of $1-5 \mathrm{hPa}$ over the $0-8 \mathrm{~km}$ altitude range, with a flow rate of 2 liters per minute per channel at sea level. For this campaign the uncertainty and accuracy for the $\Sigma$ PNs measurement was estimated to be \pm 28 pptv and $15 \%$. The individual species PAN and PPN were measured by the NCAR GC/ECD where one column measured only PAN at $\sim 2.5 \mathrm{~min}$ intervals, while the other measured PAN and PPN but on a $\sim 5$ min cycle (Flocke, et al., 2005). Both GC channels had 2-3 s sampling times. For the TOPSE data the additional interpolation of PAN from both GC channels was described by Thornton (2002). Overall, the measured $\Sigma$ PNs were consistent with the sum of the individual PAN and PPN measurements with the addition of the calculated $\mathrm{HO}_{2} \mathrm{NO}_{2}$ (Murphy, et al., 2004).

For the NASA INTEX-NA (Intercontinental Chemical Transport Experiment-North America, 1 July-15 August 2004, www.espo.nasa.gov/intex-na/) campaign (Singh, et al., 2006) using the DC-8 aircraft, the TD-LIF instrument was largely the same as for TOPSE, but with the addition of molecular jet expansions in the $\mathrm{NO}_{2} \mathrm{LIF}$ detection cells and locating additional heaters for alkyl nitrate and nitric acid channels externally in a window-panel mounted probe. The $\Sigma$ PNs and $\mathrm{NO}_{2}$ sample stream was drawn from a separate, unheated, probe. The DC-8 payload also included PAN measurements by the NASA Ames GC/ECD (Singh and Salas, 1983) and peroxynitric acid by CIMS (Kim, et al., 2007).

For the INTEX-B campaign on the NASA DC8 (www. espo.nasa.gov/intex-b/ (Singh, et al., 2009)), the TD-LIF instrument was the same except for modifications to the inlet system designed to sample $\mathrm{HNO}_{3}$ more effectively. The inlet manifold and heater assembly depicted in Fig. 1 was adapted to mount on the interior face of a window-panel and sampled from a high speed flow directed from outside the aircraft boundary layer. The external probe was the same as described by Crounse, et al. (2006). The March phase of the campaign was based in Houston, Texas and focused on outflow from Mexico City and the evolution of plumes over the Gulf of Mexico. The April-May phase was based from Honolulu, Hawaii then Anchorage, Alaska and characterized air coming across the Pacific. The NASA Ames GC/ECD instrument also measured PAN on the DC-8, 
Table 1. Measurement campaigns with TD-LIF participation

\begin{tabular}{|c|c|c|c|c|c|c|}
\hline campaign & location & year & months & platform & comparison opportunities & inlet type \\
\hline INTEX-NA & Eastern US & 2004 & June-August & NASA DC-8 & GC/ECD PAN & $\mathrm{C}$ \\
\hline $\mathrm{TC}^{4}$ & Costa Rica & 2007 & July-August & NASA DC-8 & & $\mathrm{C}$ \\
\hline ARCTAS & Arctic, California & 2008 & April-July & NASA DC-8 & TD-CIMS PANs & $\mathrm{C}$ \\
\hline TexAQS & Houston, TX & 2000 & July-August & ground site & GC/ECD PANs, $\mathrm{NO}_{y}$ & B \\
\hline Big Hill & Sierras, CA & 2003 & all months & ground site & & $\mathrm{C}$ \\
\hline Chebogue Pt. & Nova Scotia & 2004 & July-August & ground site & GC/ECD PANs & $\mathrm{C}$ \\
\hline PIE & Boulder, CO & 2005 & June-July & ground site & multiple methods, PANs & $\mathrm{C}$ \\
\hline MILAGRO & Mexico City & 2006 & March & ground site & & A \\
\hline BEARPEX & Sierras, CA & 2007 & August-October & ground site & TD-CIMS PANs & A \\
\hline
\end{tabular}

Table 2. $\Sigma$ PNs versus speciated PANs comparisons table

\begin{tabular}{|c|c|c|c|c|c|c|c|}
\hline opportunity & $\begin{array}{l}\text { weighting } \\
\%, \\
\text { ppbv } 1\end{array}$ & species in sum & slope vs. $\Sigma$ PNs & intercept ppbv & $R^{2}$ & $\begin{array}{l}\mathrm{NO}_{2} \text { ppbv } \\
\text { min., median, max. }\end{array}$ & notes \\
\hline TOPSE & & $\mathrm{PAN}+\mathrm{PPN}$ & $1.04 \pm .06$ & $.002 \pm .020$ & .77 & $.00, .013, .08$ & vs. GC/ECD \\
\hline INTEX-NA & & $\begin{array}{l}\text { PAN+PPN+PBN+PBzN+ MPAN } \\
+ \text { MoPAN+APAN }\end{array}$ & $1.06 \pm .09$ & $-.030 \pm .025$ & .88 & $.02, .06, .59$ & $\begin{array}{l}\text { vs. WP-3D TD-CIMS, } \\
\text { comparison flight }\end{array}$ \\
\hline INTEX-NA & & PAN & $1.03 \pm .01$ & $.005 \pm .003$ & .80 & $.00, .05,6.9$ & vs. DC-8 GC/ECD, full mission \\
\hline INTEX-B $^{2}$ & & PAN & $1.33 \pm .02$ & $.037 \pm .012$ & .60 & $.00, .03, .53$ & vs. DC-8 GC/ECD \\
\hline INTEX-B $^{3}$ & $20, .005$ & $\mathrm{PAN}+\mathrm{PPN}$ & $0.66 \pm .02$ & $.13 \pm .02$ & .87 & $.05, .12, .63$ & vs. C-130 TD-CIMS \\
\hline INTEX-B $^{4}$ & $20, .005$ & $\mathrm{PAN}+\mathrm{PPN}$ & $0.93 \pm .06$ & $.042 \pm .007$ & .77 & $.00, .02, .13$ & vs. C-130 TD-CIMS \\
\hline ARCTAS & & $\mathrm{PAN}+\mathrm{PPN}+\mathrm{PiBN}+\mathrm{APAN}+\mathrm{PNA}$ & $0.97 \pm .093$ & $.004 \pm .270$ & .96 & $.00, .02,59$ & vs. TD-CIMS PANs \& PNA \\
\hline ARCTAS & & $\mathrm{PAN}+\mathrm{PPN}+\mathrm{PiBN}+\mathrm{APAN}$ & $0.92 \pm .090$ & $.010 \pm .240$ & .94 & $.00, .02,59$ & without PNA $\left(\mathrm{HO}_{2} \mathrm{NO}_{2}\right)$ \\
\hline ARCTAS & & $\mathrm{PAN}+\mathrm{PPN}$ & $0.90 \pm .089$ & $.022 \pm .230$ & .94 & $.00, .02,59$ & without PNA, PiBN, APAN \\
\hline TexAQS & & $\mathrm{PAN}+\mathrm{PPN}+\mathrm{PiBN}+\mathrm{MPAN}$ & $0.91 \pm .17$ & $.024 \pm .88$ & .91 & $.80,7.7,88$ & vs. GC/ECD \\
\hline Chebogue Pt. & & $\mathrm{PAN}+\mathrm{PPN}$ & $0.90 \pm .02$ & $.005 \pm .004$ & .72 & $.00, .50,2.4$ & vs. GC/ECD \\
\hline PIE 6/ 30-7/1 & & $\mathrm{PAN}+\mathrm{PPN}$ & $0.66 \pm .08$ & $-.04 \pm .07$ & .84 & $.00,2.3,44$ & ambient sampling \\
\hline BEARPEX & $21, .003$ & PAN+PPN+MPAN & $1.08 \pm .02$ & $-.04 \pm .01$ & .75 & $.00, .73,28$ & vs. U. Wash. TD-CIMS, 2007 \\
\hline $\mathrm{N}_{2} \mathrm{O}_{5}$, Jülich & & $\mathrm{N}_{2} \mathrm{O}_{5}$ & $1.02 \pm .06$ & $-.36 \pm .05$ & .87 & $1.5,3.2,7.5$ & SAPHIR chamber runs \\
\hline
\end{tabular}

${ }^{1}$ For the TOPSE dataset $\Sigma$ PNs were weighted by $1 /(15 \%$ of measurement +.028 ppbv $)$, otherwise $\Sigma$ PNs were weighted by $1 /(15 \%$ of measurement $+.05 \mathrm{ppbv}) . \Sigma \mathrm{PAN}_{i}$ were weighted by $1 /(15 \%$ of measurement $+.005 \mathrm{ppbv})$ except when stated numbers were available, as given above.

${ }^{2}$ Gulf of Mexico and Central Pacific phases, March and April-May, 2007.

3 Intercomparison over Gulf of Mexico, 19 March 2007.

${ }^{4}$ Intercomparison over northwest US, 15 May 2007.

however, the agreement was not as good as during INTEXNA. We also participated in the 19th March and the 15th May in-flight intercomparison exercises with the NCAR/NSF C130 which was based in Veracruz, Mexico then Seattle, Washington. The C-130 payload included a TD-CIMS PANs instrument (Flocke, et al., in preparation). The DC-8 TD-LIF 19th March data correlates much better with the C-130 TDCIMS PAN+PPN than with the DC-8 GC/ECD, however the slope is significantly different from one to one. The excellent agreement between the two aircraft $\mathrm{NO}_{2}$, etc., measurements suggests that both aircraft were indeed sampling the same air masses. For the 15th May comparison, the DC-8 $\Sigma$ PNs also correlated well with the TD-CIMS PAN+PPN, however the ambient concentrations were quite low.

As a part of the Third International Polar Year research effort, measurements were made using the NASA DC-8 aircraft as a part of its ARCTAS 2008 mission (www.espo. nasa.gov/arctas/). The first phase was based in Fairbanks, Alaska, in April and concentrated on long range transport of anthropogenic and biomass burning pollution to the Arctic, 

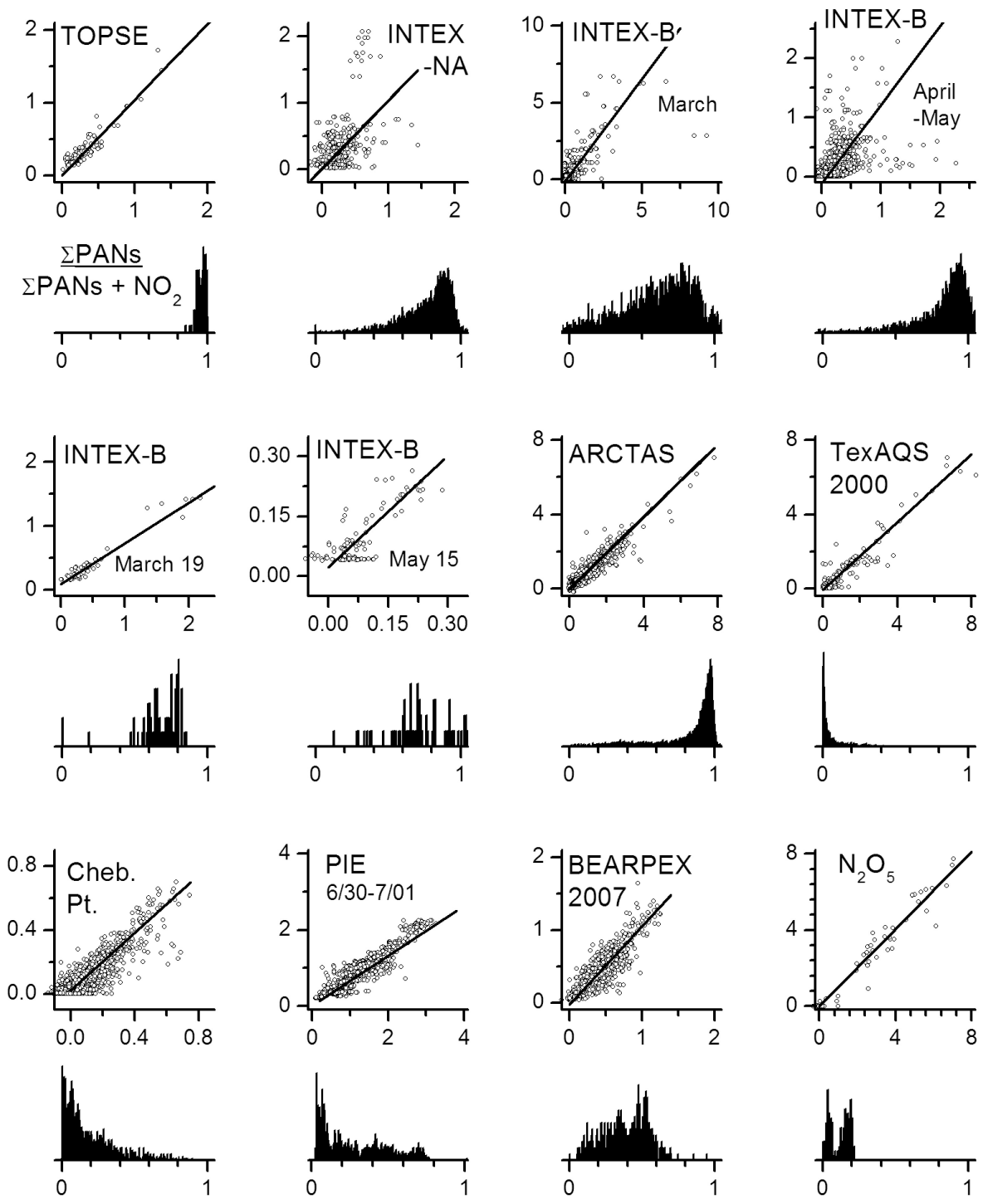

Fig. 8. Speciated $\Sigma$ PANs (ppbv) vs. TD-LIF SPNs (ppbv) scatterplots with fitted lines. Below each are histograms of the $\Sigma$ PNs fractions of the $\Sigma \mathrm{PNs}+\mathrm{NO}_{2}$ sums.

as well as chemical and aerosol composition and processes. An intermediate phase was based in southern California during June in conjunction with the California Air Resources Board to characterize ozone, particulate matter, and greenhouse gas sources and chemistry. The final phase was based in Alberta, Canada in July to sample fresh and aged boreal forest fire emissions. The TD-LIF instrument was essentially unmodified since INTEX-B. A TD-CIMS (Slusher, et al., 2004) measured the individual species. PAN and PPN, also PiBN (isobutyryl peroxynitrate) and APAN (acryloyl peroxynitrate) were reported for most flights. Peroxynitric acid (PNA), $\mathrm{HO}_{2} \mathrm{NO}_{2}$, was measured by a different CIMS (Crounse, et al., 2006). No inlet chemistry corrections were applied to the TD-LIF $\Sigma$ PNs data, instead the few points having $\mathrm{NO}>5 \mathrm{ppbv}$ were rejected. Figure 9 presents data from the final flight, in which conditions ranged from clean background to heavily impacted by biomass burning. The correlation was very good for this flight, and the entire campaign, as shown in Fig. 8. During the Arctic flights $\mathrm{HO}_{2} \mathrm{NO}_{2}$ was often well above the detection limit and was included in the full dataset correlation. As indicated in Table 2, omitting $\mathrm{HO}_{2} \mathrm{NO}_{2}$ would drop the slope from .97 to .92 and lower the $\mathrm{R}^{2}$ from .96 to .94 . The correlation plots are not sufficiently different to include in Fig. 8, but the fitted parameters are included in Table 2.

\subsection{Ground site and chamber measurements}

During the TexAQS 2000 campaign an extensive suite of ground-site measurements were made from 15 August to 15 September at LaPorte, Texas. The site was about $40 \mathrm{~km}$ 


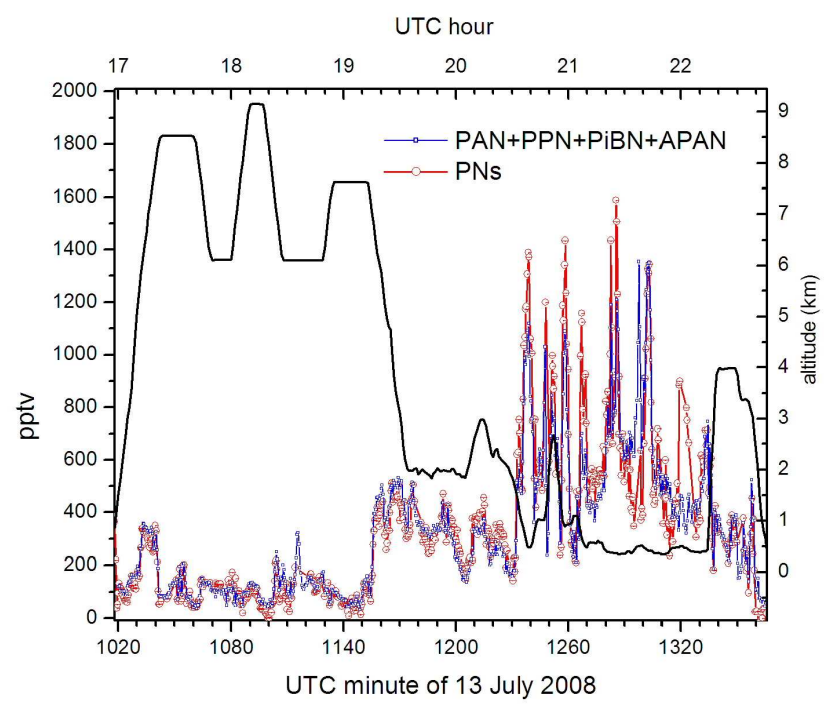

Fig. 9. TD-LIF $\Sigma$ PNs (red) and sum of speciated PANs (blue) from the TD-CIMS instrument for the ARCTAS flight from Cold Lake, Canada to Los Angeles, California. Forest fire plumes were encountered beginning at about minute 1230 .

southeast of Houston and about $20 \mathrm{~km}$ from the shipping channel where a large number of petrochemical plants are located (see e.g., Rosen et al., 2004, and references therein). The same two-channel instrument as for the airborne deployments was used here. The inlet block used in the TOPSE campaign was followed by two heated tubes modified to reach higher temperatures to enable $\Sigma$ ANs and $\mathrm{HNO}_{3}$ measurements in addition to $\mathrm{NO}_{2}$ and $\Sigma$ PNs. The pressure reducing pinholes were placed after the heated dissociation tubes (points B in Fig. 1). The inlet was mounted on a $10 \mathrm{~m}$ scaffolding tower, approximately $2 \mathrm{~m}$ below the inlet for the NOAA GC/ECD instrument (Roberts, et al., 2001). The inlet temperatures were programmed to sequentially sample $\mathrm{HNO}_{3}, \Sigma$ ANs, and $\Sigma$ PNs with $\mathrm{NO}_{2} . \mathrm{NO}_{2}$ and $\Sigma$ PNs were measured together for $40 \mathrm{~min}$ during each $5 \mathrm{~h}$ cycle. Because of the high $\mathrm{NO}_{2}$ levels (occasionally up to $100 \mathrm{ppbv}$ ), the two-channel difference had relatively high noise. In addition, artifacts from $\mathrm{NO}$ to $\mathrm{NO}_{2}$ oxidation, as well as PANs recombination in the inlet tubing were not negligible $( \pm 15 \%)$, but corrected for as described above. The GC/ECD instrument sampled the individual compounds PAN, PPN, PiBN, MPAN for approx. $3 \mathrm{~min}$ on $15 \mathrm{~min}$ intervals. The uncertainty was reported at $\pm 0.005 \mathrm{ppbv}+15 \%$ for PAN, and slightly larger for the others.

During the summer of 2004, PAN and PPN were measured by GC/ECD at the Chebogue Point, Nova Scotia ground site as part of the overall ITCT ICARTT campaign (Roberts, et al., 2002; Millet et al., 2006) along with $\Sigma$ PNs. This deployment used the compact TD-LIF instrument with the small blue diode laser described earlier. The inlet heaters were all mounted at the sampling point on the tower and the pressure reduction was at the instrument on the ground (point
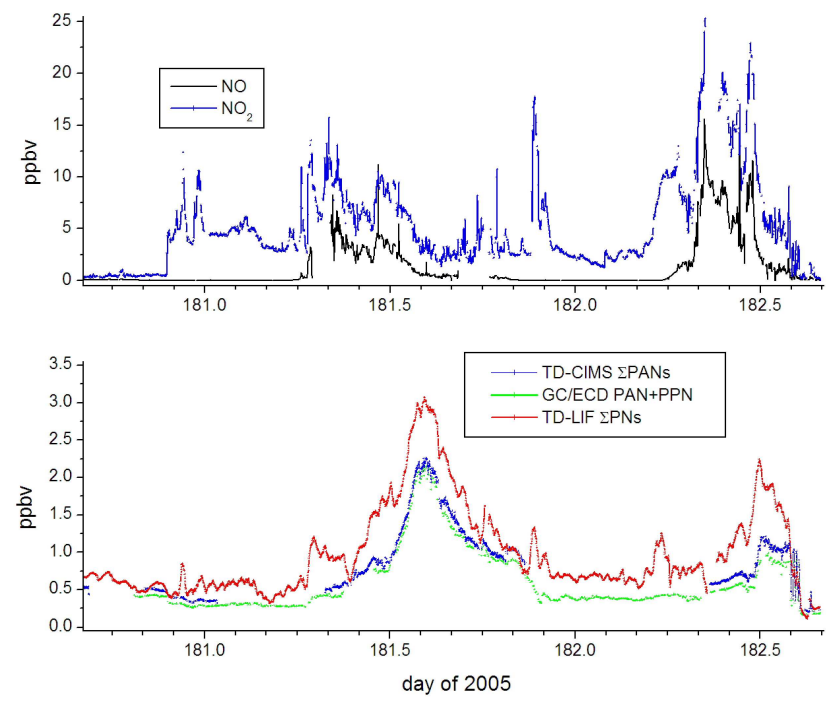

Fig. 10. PAN Intercomparison Exercise ambient sampling period: 30 June-1 July 2005, Boulder, Colorado.

C). Under these low $\mathrm{NO}_{\mathrm{x}}$ conditions, the correlation between PAN+PPN and $\Sigma$ PNs was good here despite the low concentrations of $\Sigma$ PNs relative to $\mathrm{NO}_{2}$ (Fig. 8).

The first international PAN Intercomparison Exercise (PIE, http://acd.ucar.edu/ ffl/PIE2005.html) was conducted on the Enchanted Mesa overlooking Boulder, Colorado during June and July of 2005 (Tyndall, et al., 2005). Depending on the wind direction, air arrived from the Rocky Mountains or from the heavily traveled highway corridor leading into Boulder. Instruments included five GC/ECDs (gas chromatograph/electron capture detector), TD-CIMS (thermal dissociation-chemical ionization mass spec.), GC/PDD (pulse discharge detector), GC/NICI-MS (negative ion CIMS), and TD-LIF. These were housed in five trailers (one having the standard sources and the reference GC/ECD instrument) which sampled from a common Teflon manifold having 12 to 20 SLPM flow. The instruments sampled ambient air, or were challenged with synthetic PAN (or PPN or isopropyl nitrate) standards at various humidities. Supporting measurements included $\mathrm{NO}_{2}$, $\Sigma$ ANs, and $\mathrm{HNO}_{3}$ from the TD-LIF, $\mathrm{NO}$ and $\mathrm{O}_{3}$ and basic meteorology for the early part of the exercise by NOAA. The TD-LIF instrument was the same as flown in INTEX-NA, but required longer sample lines to reach the inlet heaters mounted atop the trailer at the manifold connection. Because the pressure reduction in that instrument occurs at the LIF cell instead of at the inlet, the unanticipated high levels of $\mathrm{NO}_{\mathrm{x}}$ in the ambient air at this location lead to interferences from the $\mathrm{NO}_{2}+\mathrm{PA} \rightarrow \mathrm{PAN}$ recombination and the $\mathrm{NO}+\mathrm{PA} \rightarrow \mathrm{NO}_{2}+$ other products reaction that were more severe than those of TexAQS 2000 study. 
Figure 10 shows the results from ambient air sampled during a multi-day period that was variously impacted by fresh vehicle emissions. The temperature ranged from $15^{\circ} \mathrm{C}$ at night to $28^{\circ} \mathrm{C}$ during the day, the relative humidity 80 to $25 \%$, and the winds were light and variable. The TD-LIF $\Sigma$ PNs were greater than the sum of the speciated PANs as expected, however the deviations during the most polluted episodes were larger than usual. The correction terms calculated using the available $\mathrm{NO}, \mathrm{NO}_{2}$ and $\mathrm{O}_{3}$ data were applied to the $\Sigma$ PNs data were insufficient to bring the $\Sigma$ PNs data into agreement with the other instruments. As shown in Fig. 11 , the $\Sigma$ PNs $/ \Sigma$ PANs ratio grows when NO exceeds 1 or $2 \mathrm{ppbv}$, but the correction doesn't remove all of the NO dependence. Agreement could be achieved by choosing different parameters for these corrections; however the size of the terms needed would be larger than from the laboratory characterization. While it is possible that the extra signal had contributions from unspeciated PANs or other molecules that yield $\mathrm{NO}_{2}$ when heated to the same temperature range, overall we conclude that this inlet configuation (no pressure reduction until point $\mathrm{C}$ ) is not suited for surface sites with $\mathrm{NO}$ and $\mathrm{NO}_{2}$ levels over a few ppbv.

BEARPEX-2007 (Biosphere Effects on Aerosol and Photochemistry EXperiment, www.ocf.berkeley.edu/ bearpex/, (Cohen, et al., 2010; LaFranchi, et al., 2009)) was conducted between late August and early October, 2007 at a Ponderosa pine plantation in the Sierra Nevada foothills, a few hours downwind of the Sacramento, California urban area. The same $408 \mathrm{~nm}$ diode laser based TD-LIF instrument as had been first deployed at Chebogue Point was interfaced to an inlet system that multiplexed 4 inlets each at 3 heights to 2 LIF cells in order to measure the concentrations and vertical gradients of $\mathrm{NO}_{2}, \Sigma \mathrm{PNs}, \Sigma$ ANs, and $\mathrm{HNO}_{3}$. The University of Washington TD-CIMS measurement of PAN, PPN, and MPAN has been described by Wolfe, et al. (2008). Bouvier-Brown, et al. (2009) provides details of the large concentrations of monoterpenes (daytime average of $722 \mathrm{pptv}$ ), methylbutenol (459 pptv), isoprene (132 pptv), and other BVOCs during this experiment. LaFranchi, et al. (2009) demonstrated that BVOC oxidation plays a significant role in the PANs budget at this site. The good agreement between $\Sigma$ PANs and $\Sigma$ PNs argues against existence of large amounts of unspeciated PANs (e.g. $\mathrm{HOCH}_{2} \mathrm{C}(\mathrm{O}) \mathrm{OONO}_{2}$ ) predicted by $\mathrm{BVOC}$ oxidation mechanisms.

The $2007 \mathrm{NO}_{3} / \mathrm{N}_{2} \mathrm{O}_{5}$ intercomparison at the SAPHIR chamber in Jülich, Germany (Apodaca, et al., 2010) did not involve PANs. Nevertheless, a couple of items are of interest here. In addition to an instrument that detected $\mathrm{N}_{2} \mathrm{O}_{5}$ via TDLIF of the $\mathrm{NO}_{3}$ radical, we also provided supporting measurements of $\mathrm{NO}_{2}, \Sigma$ PNs, $\Sigma$ ANs, and $\mathrm{HNO}_{3}$ with the small diode-laser based $\mathrm{NO}_{2}$ TD-LIF instrument. As predicted in Fig. 3, we observed $\mathrm{N}_{2} \mathrm{O}_{5}$ to be quantitatively converted to $\mathrm{NO}_{2}$ in our heated inlet. Also, a point not illustrated here but relevant to the PANs budget in the ambient atmosphere is that significant quantities of PAN-type compounds were not
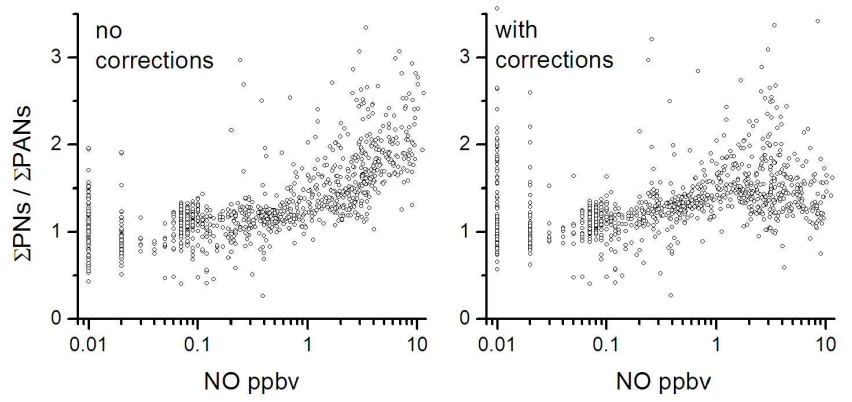

Fig. 11. Data ratios from Fig. 10 plotted against [NO], before and after applying corrections.

produced during the oxidation of isoprene, limonene, or $\beta$ pinene by $\mathrm{NO}_{3}$ during the intercomparison (Fry, et al., 2009; Rollins, et al., 2009).

\section{Discussion and conclusions}

We find good overall agreement between the TD-LIF measurement of $\Sigma$ PNs and measurements of individual PN species over a wide variety of environmental conditions. Only 3 experiments have a slope indicating differences larger than $10 \%$ (Table 2). One of these is PIE where we believe most of the ambient sampled data occurred at too high $\left(\mathrm{NO}_{\mathrm{x}}\right)$ for that inlet configuration. As a result we have discontinued use of that inlet design except for remote locations. The ARCTAS and BEARPEX campaigns sampled over a wide range of conditions from clean remote tropospheric to those heavily impacted by urban sources, by isoprene and other forest emissions and by biomass burning.

In some environments PN species other than PANs can become significant. We have shown that $\mathrm{N}_{2} \mathrm{O}_{5}$ and $\mathrm{HO}_{2} \mathrm{NO}_{2}$ are measured as PNs by our instrument. It seems probable that $\mathrm{CH}_{3} \mathrm{O}_{2} \mathrm{NO}_{2}$ is also detected, but that is never expected to be above a few 10s of pptvs, and only then in the coldest regions of the upper troposphere (Murphy et al., 2004; Browne, et al., 2010). Previous inlet systems had not been designed to put $\mathrm{CH}_{3} \mathrm{O}_{2} \mathrm{NO}_{2}$ unambiguously into the PNs channel versus the unheated $\mathrm{NO}_{2}$ channel, but that would require little modification to ensure that $\mathrm{CH}_{3} \mathrm{O}_{2} \mathrm{NO}_{2}$ dissociates only in the PNs channel. Other species such as $\mathrm{ClONO}_{2}$ or $\mathrm{BrONO}_{2}$ would also be expected to largely dissociate in the PNs heater, but we do not have data on whether they would survive the Teflon inlet plumbing to reach the heater.

The results argue that the sum of any unmeasured PN species contributes less than $10 \%$ to the $\Sigma$ PNs budget on average. Even for specific cases where aldehyde and other sources of potential unmeasured individual PAN species are large (the forest site) we find that $\Sigma$ PNs and the sum of individual species agree to within $8 \%$. Chamber data and ambient observations also suggest that significant PNs are not formed by nighttime $\mathrm{NO}_{3} / \mathrm{N}_{2} \mathrm{O}_{5}$ oxidation of biogenic volatile organic compounds. 
Acknowledgements. The Berkeley authors gratefully acknowledge funding from NSF grants ATM-1038669, ATM-0639847, ATM0511829, and Office of Polar Programs Grant No. 9907928; NASA grants NNG05GH196, NAG5-13668, NNX08AE56G, and Instrument Incubator Program contract NAS1-99053; and NOAA grant RA133R-04-AE-0023. The $\mathrm{NO}_{3}-\mathrm{N}_{2} \mathrm{O}_{5}$-Intercomparison campaign (2007) was supported by grant no. RII3-CT-2004-505968 of the European Community within the 6th Framework Program, Section Support for research Infrastructures - Integrated Infrastructure Initiative: EUROCHAMP 15 and Priority 1.1.6.3. Global Change and Ecosystems: ACCENT. Thanks also to S. Brown, H. Fuchs, and W. Dubé for $\mathrm{N}_{2} \mathrm{O}_{5}$ for providing the NOAA cavity ring-down $\mathrm{N}_{2} \mathrm{O}_{5}$ data.

Edited by: J. Staehelin

\section{References}

Alaghmand, M., Slade, N. J., Mielke, L., Starn, T., Carroll, M., Bertman, S. B., Stevens, P.S., and Shepson, P.B., Determination of reactive nitrogen species $\left(\mathrm{NO}_{\mathrm{x}}, \mathrm{NO}_{\mathrm{y}}-\mathrm{HNO}_{3}\right.$, Peroxyacetyl $\mathrm{Ni}$ trates, Total Organic Nitrates) during PROPHET summer 2008 intensive, Eos Trans. AGU, 89(53), Fall Meet. Suppl., Abstract A31A-0069, 2008.

Anderson, L. C. and Fahey, D. W.: Studies with $\mathrm{ClONO}_{2}$ : thermal dissociation rate and catalytic conversion to nitric oxide using an $\mathrm{NO} / \mathrm{O}_{3}$ chemiluminescence detector, J. Phys. Chem., 94, 644652, 1990.

Apodaca, R. L., Simpson, W. R., Ball, S. M., Bauers, T., Brown, S. S., Cohen, R. C., Crowley, J., Dorn, H.-P., Dube, W. P., Fry, J. L., Fuchs, H., Haseler, R., Heitnam, U., Kato, S., Kajii, Y., KiendlerScharr, A., Kleffmann, J., Labazan, I., Matsumoto, J., Nishada, S., Rollins, A. W., Tillmann, R., Wahner, A., Wegener, R., and Wooldridge, P. J.: Intercomparison of $\mathrm{N}_{2} \mathrm{O}_{5}$ sensors using the SAPHIR reaction chamber, Atmos. Chem. and Phys. Discuss., in preparation, 2010.

Atlas, E. L., Ridley, B. A., and Cantrell, C.: The Tropospheric Ozone Production about the Spring Equinox (TOPSE) experiment: Introduction, J. Geophys. Res., 108, 8353, doi:10.1029/2002JD003172, 2003.

Baulch, D. L., Duxbury, J., Grant, S. J., and Montague, D. C.: Evaluated kinetic data for high temperature reactions. Volume 4 Homogeneous gas phase reactions of halogen- and cyanide- containing species, J. Phys. Chem. Ref. Data, Supplement No. 1 to vol. $10,1981$.

Bertram, T. H., Perring, A. E., Wooldridge, P. J., Crounse, J. D., Kwan, A. J., Wennberg, P. O., Scheuer, E., Dibb, J., Avery, M., Sachse, G., Vay, S. A., Crawford, J. H., McNaughton, C. S., Clark, A., Pickering, K. E., Fuelberg, H., Huey, L. G., Blake, D. R., Singh, H. B., Hall, S. R., Shetter, R. E., Fried, A., Heikes, B. G., and Cohen, R. C., Direct Measurements of the Convective Recycling of the Upper Troposphere, Science, 315, 816-820, 2007.

Blanchard, P., Shepson, P. B., So, K. W., Schiff, H. I., Bottenheim, J. W., Gallant, A. J., Drummond, J. W., and Wong, P, A comparison of calibration and measurement techniques for gas chromatographic determination of atmospheric peroxyacetyl nitrate (PAN), Atmos. Environ., 24A, 2839-2846, 1990.
Blanchard, P., Shepson, P. B., Schiff, H. I., and Drummond, J. W.: Development of a gas chromatograph for trace level measurement of peroxyacetyl nitrate using chemical amplification, Anal. Chem., 65, 2472-2477, 1993.

Bouvier-Brown, N. C., Goldstein, A. H., Gilman, J. B., Kuster, W. C., and de Gouw, J. A.: In-situ ambient quantification of monoterpenes, sesquiterpenes, and related oxygenated compounds during BEARPEX 2007: implications for gas- and particle-phase chemistry, Atmos. Chem. Phys., 9, 5505-5518, 2009 , http://www.atmos-chem-phys.net/9/5505/2009/.

Bowman, J. H., Basket, D. J., and Shepson, P. B.: Atmospheric chemistry of nonanal, Environ. Sci. Tech., 37, 2218-2225, 2003.

Brown, S. S., deGouw, J. A., Warneke, C., Ryerson, T. B., Dub, W. P., Atlas, E., Weber, R. J., Peltier, R. E., Neuman, J. A., Roberts, J. M., Swanson, A., Flocke, F., McKeen, S. A., Brioude, J., Sommariva, R., Trainer, M., Fehsenfeld, F. C., and Ravishankara, A. R.: Nocturnal isoprene oxidation over the Northeast United States in summer and its impact on reactive nitrogen partitioning and secondary organic aerosol, Atmos. Chem. Phys. Discuss., 9, 225-269, 2009,

http://www.atmos-chem-phys-discuss.net/9/225/2009/.

Browne, E. C., Perring, A. E., Wooldridge, P. J., Cohen, R. C., et al.: $\mathrm{CH}_{3} \mathrm{OONO}_{2}$ in the remote troposphere: Implications for $\mathrm{NO}_{2}$ measurements and photochemistry, in preparation, 2010.

Cabañas, B., Salgado. S., Martin, P., Baeza, M. T., Albaladejo, J., and Martinez, E.: Gas-phase rate coefficients and activation energies for the reaction of $\mathrm{NO}_{3}$ radicals with selected branched aliphatic aldehydes, Phys. Chem. Chem. Phys., 5, 112-116, 2003.

Carrasco, N., Doussin, J.-F., Picquet-Varrault, B., and Carlier, P.: Tropospheric degradation of 2-hydroxy-2-methylpropanal, a photo-oxidation product of 2-methyl-3-buten-2-ol: Kinetic and mechanistic study of its photolysis and its reaction with $\mathrm{OH}$ radicals, Atmos. Environ., 40, 2011-2019, 2006.

Cicciolli, P. and Mannozzi, M.: High-Molecular-Weight Carbonyls and Carboxylic Acids, in: Volatile Organic Compounds in the Atmosphere, R. Koppmann ed., Blackwell, Ames, Iowa, USA, 292-341, 2007.

Cleary, P. A., Wooldridge, P. J., and Cohen, R. C.: Laser-induced Fluorescence Detection of Atmospheric $\mathrm{NO}_{2}$ Using a Commercial Diode Laser and a Supersonic Expansion, Appl. Optics, 41, 6950-6956, 2002.

Cleary, P. A., Murphy, J. G., Wooldridge, P. J., Day, D. A., Millet, D. B., McKay, M., Goldstein, A. H., and Cohen, R. C.: Observations of total alkyl nitrates within the Sacramento Urban Plume, Atmos. Chem. Phys. Discuss., 5, 4801-4843, 2005, http://www.atmos-chem-phys-discuss.net/5/4801/2005/.

Cleary, P. A., Wooldridge, P. J., Millet, D. B., McKay, M., Goldstein, A. H., and Cohen, R. C.: Observations of total peroxy nitrates and aldehydes: measurement interpretation and inference of $\mathrm{OH}$ radical concentrations, Atmos. Chem. Phys., 7, 19471960, 2007, http://www.atmos-chem-phys.net/7/1947/2007/.

Cohen, R. C., Goldstein, A. H. McKay, M., et al., The Biosphere Effects on Aerosol and Photochemistry Experiment 2007 (BEARPEX-2007), Atmos. Chem. Phys., in preparation, 2010.

Crounse, J. D., McKinney, K. A., Kwan, A. J., and Wennberg, P. O.: Measurement of gas-phase hydroperoxides by chemical ion- 
ization spectrometry, Anal. Chem., 78, 6726-6732, 2006.

D’Anna, B., Anderson, Ø., Gefen, Z., and Nielson, C. J.: Kinetics of $\mathrm{OH}$ and $\mathrm{NO}_{3}$ radical reactions with 14 aliphatic aldehydes, Phys. Chem. Chem. Phys., 3(15) 3057-3063, 2001.

Day, D. A., Wooldridge, P. J., Dillon, M. B., Thornton, J. A., and Cohen, R. C.: A thermal dissociation laser-induced fluorescence instrument for in situ detection of $\mathrm{NO}_{2}$, peroxynitrates, alkyl nitrates, and $\mathrm{HNO}_{3}$, J. Geophys. Res., 107(D5), 4046, doi:10.1029/2001JD000779, 2002.

Di Carlo, P., Dari-Salisburgo, C., Aruffo, E., and Giammaria, F.: The behavior of the nitrogen dioxide, total peroxy nitrates, and total alkyl nitrates in the Borneo forest during 2008 OP3 campaign, Eos Trans. AGU, 89(53), Fall Meet. Suppl., Abstract A11C-0141, 2008.

Flocke, F. M., Weinheimer, A. J., Swanson, A. L., Roberts, J. M., Schmitt, R., and Shertz, S.: On the Measurement of PANs by Gas Chromatography and Electron Capture Detection, J. Atmos. Chem., 52, 19-43, 2005.

Fry, J. L., Kiendler-Scharr, A., Rollins, A. W., Wooldridge, P. J., Brown, S. S., Fuchs, H., Dubé, W., Mensah, A., dal Maso, M., Tillmann, R., Dorn, H.-P., Brauers, T., and Cohen, R. C.: Organic nitrate and secondary organic aerosol yield from $\mathrm{NO}_{3}$ oxidation of $\beta$-pinene evaluated using a gas-phase kinetics/aerosol partitioning model, Atmos. Chem. Phys., 9, 1431-1449, 2009, http://www.atmos-chem-phys.net/9/1431/2009/.

Fuchs, H., Ball, S. M., Brauers, T., Cohen, R. C., Dorn, H.-P., Dubé, W. P., Fry, J., Häseler, R., Kleffmann, J., Müsgen, P., Rohrer, F., Rollins, D., Ruth, A. A., Schlosser, E., Shillings, A., Tillmann, R., Venables, D. S., Varma, R. M., Villena Tapia, G., Wegener, R., Wooldridge, P. J., Wahner, A., and Brown, S. S., Intercomparison of $\mathrm{NO}_{2}$ measurements from at the atmosphere simulation chamber SAPHIR during the NO3Comp campaign, Atmos. Meas. Tech. Discuss, 2, 2539-2586, 2009.

Glatthor, N., von Clarmann, T., Fischer, H., Funke, B., Grabowski, U., Höpfner, M., Kellmann, S., Kiefer, M., Linden, A., Milz, M., Steck, T., and Stiller, G. P.: Global peroxyacetyl nitrate (PAN) retrieval in the upper troposphere from limb emission spectra of the Michelson Interferometer for Passive Atmospheric Sounding (MIPAS), Atmos. Chem. Phys., 7, 2775-2787, 2007, http://www.atmos-chem-phys.net/7/2775/2007/.

Grossman, D., Moortgat, G. K., Kibler, M., Schlomski, S., Bachman, K., Alicke, B., Geyer, A., Platt, U., Hammer, M. U., Vogel, B., Mehelcic, D., Hofzumahaus, A., Holland, F., and Volz-thomas, A.: Hydrogen peroxide, organic peroxides, carbonyl compounds, and organic acids measured at Pabstthum during BERLIOZ, J. Geophys. Res., 108, 8250, doi:10.1029/2001JD001096, 2003.

Horowitz, L. W., Jiang, J. Y., Gardner, G. M., and Jacob, D. J.: Export of reactive nitrogen from North America during summertime: Sensitivity to hydrocarbon emissions, J. Geophys. Res., 103, 13451-13476, 1998.

Horowitz, L. W., Fiore, A. M., Milly, G. P., Cohen, R. C., Perring, A., Wooldridge, P. J., Hess, P. G., Emmons, L. K., and Lamarque, J.-F.: Observational constraints on the chemistry of isoprene nitrates over the eastern United States, J. Geophys. Res., 112, D12S08, doi:10.1029/2006JD007747, 2007.

Hudman, R. C., Jacob, D. J., Cooper, O. C., Evans, M. J., Heald, C. L. Park., R. J., Fehsenfeld, F., Flocke, F., Holloway, J., Hubler, G., Kita, K., Koike, M., Kondo, Y., Neuman, A., Nowak, J., Olt- mans, S., Parrish, D., Roberts, J. M., and Ryerson, T.: Ozone production in transpacific Asian pollution plumes and implications for ozone air quality in California, J. Geophys. Res., 109, D23S10, doi:10.1029/2004JD004974, 2004.

Kim, S., Huey, L. G., Stickel, R. E., Tanner, D. J., Crawford, J. H., Olsen, J. R., Chen, G., Brune, W. H., Ren, X., Lesher, R., Wooldridge, P. J., Bertram, T. H., Perring, A. E., Cohen, R. C., Lefer, B., Shetter, R. E., Avery, M., Disken, G., and Sokolik, I.: Measurement of $\mathrm{HO}_{2} \mathrm{NO}_{2}$ in the INTEX-NA, J. Geophys. Res., 112, D12S01, doi:10/1029/2006JD007676., 2007.

Knauth, H. D. and Martin, H.: Thermal decomposition of $\mathrm{ClNO}_{2}$, Z. Naturforsch., 33a, 1037-1047, 1978.

Krystek, M. and Anton, M.: A weighted total least-squares algorithm for fitting a straight line, Meas. Sci. Technol., 18, 34383442, 2007.

LaFranchi, B. W., Wolfe, G. M., Thornton, J. A., Harrold, S. A., Browne, E. C., Min, K. E., Wooldridge, P. J., Gilman, J. B., Kuster, W. C., Goldan, P. D., deGouw, J. A., McKay, M., Goldstein, A. H., Ren, X., Mao, J., and Cohen, R. C.: Closing the peroxy acetyl (PA) radical budget: observations of acyl peroxy nitrates (PAN, PPN, and MPAN) during BEARPEX 2007, Atmos. Chem. Phys. Discuss., 9, 9879-9926, 2009,

http://www.atmos-chem-phys-discuss.net/9/9879/2009/.

Lewis, C. A., Carslaw, N., Marriott, P. J., Kinghorn, R. M., Morrison, P., Lee, A. L., Bartle, K. D., and Pilling, M. J.: A larger pool of ozone-forming carbon compounds in urban atmospheres, Nature, 405, 778-781, 2000.

McClenny, W. A., Daughtrey, E. H., Adams, J. R., Oliver, K. D., and Kronmiller, K. G.: Volatile Organic Compound Concentration Patterns at the New Hendersonville Monitoring Site in the 1995 Southern Oxidants Study in the Nashville, Tennessee Area, J. Geophys. Res., 103, 22509-22518, 1998.

Méreau, R., Rayez, M.-T., Rayez, J.-C., Caralp, F., and Lesclaux, R.: Theoretical study on the atmospheric fate of carbonyl radicals: kinetics of decomposition reactions, Phys. Chem. Chem. Phys., 3, 4712-4717, 2001.

Millet, D. B., Goldstein, A. H., Holzinger, R., Williams, B., Allan, J. D., Jimenez, J. L.,. Worsnop, D. R., Roberts, J. M., White, A. B., Hudman, R. C., Bertschi, I. T., and Stohl, A.: Chemical characteristics of North American surface-layer outflow: Insights from Chebogue Point, Nova Scotia, J. Geophys. Res., 111, D23S53, doi:10.1029/2006JD007287, 2006.

Murphy, J. G., Thornton, J. A., Wooldridge, P. J., Day, D. A., Rosen, R. S., Cantrell, C., Shetter, R. E., Lefer, B., and Cohen, R. C.: Measurements of the sum of $\mathrm{HO}_{2} \mathrm{NO}_{2}$ and $\mathrm{CH}_{3} \mathrm{O}_{2} \mathrm{NO}_{2}$ in the remote troposphere, Atmos. Chem. Phys., 4, 377-384, 2004, http://www.atmos-chem-phys.net/4/377/2004/.

Murphy, J. G., Day, D. A., Cleary, P. A., Wooldridge, P. J., and Cohen, R. C.: Observations of the diurnal and seasonal trends in nitrogen oxides in the western Sierra Nevada, Atmos. Chem. Phys., 6, 5321-5338, 2006, http://www.atmos-chem-phys.net/6/5321/2006/.

Neuman, J. A., Gao, R. S., Schein, M. E., Ciciora, S. J., Holocek, J. C., Thompson, T. L., Winkler, R. H., McLaughlin, R. J., Northway, M. J., Richard, E. C., and Fahey, D. W.: A fast-response chemical ionization mass spectrometer for in situ measurements of $\mathrm{HNO}_{3}$ in the upper troposphere and lower stratosphere, Rev. Sci. Inst., 71, 3886-3894, 2000.

Nikitas, C., Clemitshaw, K. C., Oram, D. E., and Penkett, S. A.: 
Measurements of PAN in the polluted boundary layer and free troposphere using a Luminol- $\mathrm{NO}_{2}$ detector combined with a thermal convertor, J. Atmos. Chem., 28, 339-359, 1997.

Orlando, J. J. and Tyndall, G. S.: Rate coefficients for the thermal decomposition of $\mathrm{BrONO}_{2}$ and the heat of formation of $\mathrm{BrONO}_{2}$, J. Phys. Chem., 100, 19398-19405, 1996.

Orlando, J. J. and Tyndall, G. S.: The atmospheric chemistry of the HC(O)CO radical, Int. J. Chem. Kinetics, 33, 149-156, 2001.

Osthoff, H. D., Roberts, J. M, Ravishankara, A. A., Williams, Eric J., Lerner, B. M., Sommariva, R, Bates, T. S., Coffman, D., Quinn, P. K., Dibb, J. E., Stark, H., Burkholder, J. B., Talukdar, R. K, Meagher, J., Fehsenfeld, F. C. and Brown, S. S.: High levels of nitryl chloride in the polluted subtropical marine boundary layer, Nat. Geosci., 1, 324-328, 2008.

Parrish, D. D., Dunlea, E. J., Atlas, E. L., Schauffler, S., Donnelly, S., Stroud, V., Goldstein, A. H., Millet, D. B., McKay, M., Jaffe, D. A., Price, H. U., Hess, P. G., Flocke, F., and Roberts, J. M.: Changes in the photochemical environment of the temperate North Pacific troposphere in response to increased Asian emissions, J. Geophy. Res., 109, D23S18, doi:10.1029/2004JD004978, 2004.

Parrish, D. D., Millet, D. B., and Goldstein, A. H.: Increasing ozone in marine boundary layer inflow at the west coasts of North America and Europe, Atmos. Chem. Phys., 9, 1303-1323, 2009, http://www.atmos-chem-phys.net/9/1303/2009/.

Paul, D., Furgeson, A, and Osthoff, H. D.: Measurement of total peroxy and alkyl nitrate abundances in laboratory-generated gas samples by thermal decomposition cavity ring-down spectroscopy, Rev. Sci. Instrum., 80, 114101, 2009.

Perring, A. E., Wisthaler, A., Graus, M., Wooldridge, P. J., Lockwood, A. L., Mielke, L. H., Shepson, P. B., Hansel, A., and Cohen, R. C.: A product study of the isoprene $+\mathrm{NO}_{3}$ reaction, Atmos. Chem. Phys. Discuss., 9, 5231-5261, 2009, http://www.atmos-chem-phys-discuss.net/9/5231/2009/.

Perring, A. E., Bertram, T. H., Wooldridge, P. J., Fried, A., Heikes, B. G., Dibb, J., Crounse, J. D., Wennberg, P. O., Blake, N. J., Blake, D. R., Brune, W. H., Singh, H. B., and Cohen, R. C.: Airborne observations of total $\mathrm{RONO}_{2}$ : new constraints on the yield and lifetime of isoprene nitrates, Atmos. Chem. Phys., 9, 1451-1463, 2009,

http://www.atmos-chem-phys.net/9/1451/2009/.

Roberts, J. M.: The Atmospheric Chemistry of Organic Nitrates, Atmos. Environ., 24, 243-287, 1990.

Roberts, J. M. and Bertman, S. B.: The Thermal Decomposition of PeroxyAcetic Nitric Anhydride (PAN) and Peroxymethacrylic Nitric Anhydride (MPAN), Intl. J. Chem. Kinet., 24, 297-307, 1992.

Roberts, J. M., Williams, J., Baumann, K., Buhr, M. P., Goldan, P. D., Holloway, J., Hubler, G., Kuster, W. C., McKeen, S. A., Ryerson, T. B., Trainer, M., Williams, E. J., Fehsenfeld, F. C., Bertman, S. B., Nouaime, G., Seaver, C., Grodzinsky, G., Rodgers, M., and Young, V. L., Measurements of PAN, PPN, and MPAN made during the 1994 and 1995 Nashville Intensives of the Southern Oxidants Study: Implications for regional ozone production from biogenic hydrocarbons, J. Geophys. Res., 103, 22473-22490, 1998.

Roberts, J. M., Stroud, C. A., Jobson, B. T., Trainer, M., Hereid, D., Willaims E., Fehsenfeld, F., Brune, W., Martinez, M., and Harder. H.: Application of sequential reaction model to PANs and aldehyde measurements in two urban areas, Geophys. Res. Lett., 28, 4583-4586, 2001.

Roberts, J. M., Flocke, F., Stroud, C. A., Hereid, D., Williams, E., Fehsenfeld, F., Brune, W., Martinez, M., Harder, H., Ground-based measurements of peroxycarboxylic nitric anhydrides (PANs) during the 1999 Southern Oxidants Study Nashville Intensive, J. Geophys. Res., 107, 4554, doi:10.1029/2001JD000947, 2002.

Roberts, J. M.: PAN and Related Compounds, in: Volatile Organic Compounds in the Atmosphere, R. Koppmann ed., Blackwell, Ames, Iowa, USA, 221-268, 2007.

Rollins, A. W., Kiendler-Scharr, A., Fry, J., Brauers, T., Brown, S. S., Dorn, H.-P., Dubé, W. P., Fuchs, H., Mensah, A., Mentel, T. F., Rohrer, F., Tillmann, R., Wegener, R., Wooldridge, P. J., and Cohen, R. C.: Isoprene oxidation by nitrate radical: alkyl nitrate and secondary organic aerosol yields, Atmos. Chem. Phys. Discuss., 9, 8857-8902, 2009,

http://www.atmos-chem-phys-discuss.net/9/8857/2009/.

Romero, M. T. B., Blitz, M. A., Heard, D. E., Pilling, M. J., Price, B, Seakins, P. W., and Wang, L.: Photolysis of methylethyl, diethyl and methylvinyl ketones and their role in the atmospheric $\mathrm{HO}_{\mathrm{x}}$ budget, Faraday Discuss., 130, 73-88, 2005.

Rosen, R. S., Wood, E. C., Wooldridge, P. J., Thornton, J. A., Day, D. A., Kuster, W., Williams, E. J., Jobson, B. T., and Cohen, R. C.: Observations of Total Alkyl Nitrates during TexAQS-2000: implications for $\mathrm{O}_{3}$ and alkyl nitrate photochemistry, J. Geophys. Res., 109, D0730303, doi:10.1029/2003JD004227, 2004.

Ryerson, T. B., Huey, L. G., Knapp, K., Neuman, J. A., Parish, D. D., Sueper, D. T., and Fehsenfeld, F. C.: Design and initial characterization of an inlet for gas phase $\mathrm{NO}_{y}$ measurements from aircraft, J. Geophys. Res., 104, 5483-5492, 1999.

Ryerson, T. B., Williams, E. J., and Fehsenfeld, F. C.: An efficient photolysis system for fast-response $\mathrm{NO}_{2}$ measurements, J. Geophys. Res., 105, 26447-26461, 2000.

Salawitch, R. J., Wennberg, P. O., Toon, G. C., Sen, B., and Blavier, J.-F.: Near IR photolysis of $\mathrm{HO}_{2} \mathrm{NO}_{2}$ : Implications for $\mathrm{HO}_{\mathrm{x}}$, Geophys. Res. Lett., 29, 1762, doi:10.1029/2002GL015006, 2002.

Saunders, S. M., Jenkin, M. E., Derwent, R. G., and Pilling, M. J.: Protocol for the development of the Master Chemical Mechanism, MCM v3 (Part A): tropospheric degradation of nonaromatic volatile organic compounds, Atmos. Chem. Phys., 3, 161-180, 2003, http://www.atmos-chem-phys.net/3/161/2003/.

Singh, H. B. and Salas, L. J.: Methodology for the analysis of peroxyacetyl nitrate (PAN) in the unpolluted atmosphere, Atmos. Environ., 17, 1507-1516, 1983.

Singh, H. B.: Reactive nitrogen in the troposphere, Environ. Sci. Technol., 21, 320-327, 1987.

Singh, H. B.: Tropospheric Composition and Analysis: PAN, in Encyclopedia of Atmospheric Sciences: Holton, J., Pyle, J., and Curry, J., Academic Press, London, Vol. 6, 2424-2428, 2003.

Singh, H. B., Brune, W., Crawford, J., Jacob, D., and Russell, P. B.: Overview of the Summer 2004 Intercontinental Chemical Transport Experiment-North America (INTEX-A), J. Geophy. Res., 111, D24S01, doi:1029.2006JD007905, 2006.

Singh, H. B., Brune, W. H., Crawford, J. H., Flocke, F., and Jacob, D. J.: Chemistry and transport of pollution over the Gulf of Mexico and the Pacific: spring 2006 INTEX-B campaign overview 
and first results, Atmos. Chem. Phys., 9, 2301-2318, 2009, http://www.atmos-chem-phys.net/9/2301/2009/.

Slusher, D., Huey, L. G., Tanner, D. J., Flocke, F. M., and Roberts, J. M.: A thermal dissociation chemical ionization mass spectrometry (TD-CIMS) technique for the simultaneous measurement of peroxyacyl nitrates and dinitrogen pentoxide, J. Geophys. Res., 109, D19315, doi:10.1029/2004JD004670, 2004.

Stephens, E. R.: The formation, reactions and properties of peroxyacyl nitrates (PANs) in photochemical air pollution, Adv. Environ. Sci. Technol., 1, 119-146, 1969.

Thornton, J. A., Wooldridge, P. J., and Cohen, R. C.: Atmospheric $\mathrm{NO}_{2}$ : In situ laser-induced fluorescence detection at parts per trillion mixing ratios, Anal. Chem., 72, 528-539, 2000.

Thornton, J. A.: Nitrogen Dioxide, Peroxynitrates, and the Chemistry of Tropospheric Ozone Production: New Insights from In Situ Measurements, Ph.D. thesis, University of California, Berkeley, 2002.

Thornton, J. A., Wooldridge, P. J., Cohen, R. C., Williams, E. J., Hereid, D., Fehsenfeld, F. C., Stutz, J., and Alicke, B.: Comparisons of in situ and long path measurements of $\mathrm{NO}_{2}$ in urban plumes, J. Geophys. Res., 108, 4496, doi:10.1029/2003JD003559, 2003.

Turnipseed, A. A., Huey, L. G., Nemitz, E., Stickel, R., Higgs, J., Tanner, D. J., Slusher, D. L., Sparks, J. P., Flocke, F., and Guenther, A.: Eddy covariance fluxes of peroxyacetyl nitrates (PANs) and $\mathrm{NO}_{\mathrm{y}}$ to a coniferous forest, J. Geophys. Res., 111, doi:10.1029/2005JD006631, 2006.

Tyndall, G. S., Orlando, J. J., Wallington, T. J., Hurley, M. D., Goto, M., and Kawasaki, M.: Mechanism of the reaction of $\mathrm{OH}$ with acetone and acetaldehyde at $251 \& 295 \mathrm{~K}$, Phys. Chem. Chem. Phys., 4, 2189-2193, 2002.
Tyndall, G., Apel, E., Williams, E., Flocke, F., Cohen, R., Gilge, S., Kim, S., Mills, G., O’Brien, J., Perring, A., Rappenglueck, B., Roberts, J., Schmitt, R., Swanson, A., Tanimoto, H., and Wooldridge, P.: PIE 2005: An intercomparison of measurement techniques for peroxynitrates (PANs), Eos Trans. AGU, 86(52), Fall Meet. Suppl., Abstract A13C-0941, 2005.

Wedel, A., Muller, K. P., Ratte, M., and Rudolph, J.: Measurements of volatile organic compounds (VOC) during POPCORN 1994: Applying a new on-line GC-MS-technique, J. Atmos. Chem., 31, 73-103, 1998.

Wolfe, G. M., Yatavelli, R. L. N., Thornton, J. A., McKay, M., Goldstein, A. H., LaFranchi, B., Min, K.-E., and Cohen, R. C.: Eddy covariance fluxes of acyl peroxy nitrates (PAN, PPN, and MPAN) above a Ponderosa pine forest, Atmos. Chem. Phys. Discuss., 8, 17495-17548, 2008,

http://www.atmos-chem-phys-discuss.net/8/17495/2008/.

Yokouchi, Y., Hitoshi, M., Nakajima, K., and Ambe, Y.: Semivolatile aldehydes as predominant organic gases in remote areas, Atmos. Environ., 24A, 439-442, 1990.

Zabel, F., Reimer, A., Becker, K. H., and Fink, E. H.: Thermal decomposition of alkyl peroxynitrates, J. Phys. Chem., 93, 55005507, 1989.

Zhang, L., Jacob, D. J., Boersma, K. F., Jaffe, D. A., Olson, J. R., Bowman, K. W., Worden, J. R., Thompson, A. M., Avery, M. A., Cohen, R. C., Dibb, J. E., Flock, F. M., Fuelberg, H. E., Huey, L. G., McMillan, W. W., Singh, H. B., and Weinheimer, A. J.: Transpacific transport of ozone pollution and the effect of recent Asian emission increases on air quality in North America: an integrated analysis using satellite, aircraft, ozonesonde, and surface observations, Atmos. Chem. Phys., 8, 6117-6136, 2008, http://www.atmos-chem-phys.net/8/6117/2008/. 